IN MEMORIAM: AN ODE TO MELANCHOLY AND RELIGION IN TENNYSON'S MAGNUM OPUS

\author{
A Thesis submitted to the faculty of \\ San Francisco State University \\ In partial fulfillment of \\ the requirements for \\ the Degree
}

Master's Degree

In

English Literature

by

Melissa Thea Valk

San Francisco, California

Fall 2020 
Copyright by

Melissa Thea Valk 2020 


\section{CERTIFICATION OF APPROVAL}

I certify that I have read I certify that I have read "In Memoriam:" An Ode to Melancholy and Religion in Tennyson's Magnum Opus" by Melissa Thea Valk, and that in my opinion this work meets the criteria for approving a thesis submitted in partial fulfillment of the requirement for the degree Master of Arts in English Literature at San Francisco State University.

Summer Star, Ph.D.

Assistant Professor

Sara Hackenberg, Ph.D.

Associate Professor 


\title{
IN MEMORIAM: AN ODE TO MELANCHOLY AND RELIGION IN TENNYSON'S MAGNUM OPUS
}

\author{
Melissa Thea Valk \\ San Francisco, California
}

2020

This thesis dissects the role of melancholic imagery and religion in Alfred Tennyson's poetry, with a special focus on his magnum opus, In Memoriam A.H.H (1850) and how the use of melancholy and religion act as rhetorical tropes in conveying the depths of his grief after losing his dear friend, Arthur Hallam. Furthermore, I analyzed particular cantos adjacent to a few of his other poems such as "The Lady of Shalott" (1833 and 1842), "Mariana" (1830), and "The Sleeping Beauty" (1830). The use of melancholic imagery is abundant in Tennyson's work, but this thesis argues that upon the death of Arthur Hallam, Tennyson reconfigured his melancholic aesthetic that we see in his older poems to fit the melancholic tone in his elegy. Therefore, I trace Tennsyon's original aesthetic of melancholy in his more fantastical works and how he reconfigures his aesthetic through the writing process of In Memoriam, shifting from a romantic and colorful melancholy to a confrontation of a dark and grim grief and its place in the interrelation between faith and doubt. The shift in Tennyson's aesthetic of melancholy and cantos in In Memoriam work brilliantly together when intertwined not only with each other, but also with Tennyson's beautiful command of meter, diction, and syllabic dexterity. The death of Tennyson's beloved friend Arthur Hallam was the catalyst for Tennyson's artistic manifestation of grief and doubt employed in In Memoriam as well as the religious odyssey Tennyson embarks on for seventeen years after Hallam's death. This grief and doubt intertwine with Tennyson's reconfigured aesthetic and serves to speak to and unite his Victorian audience because they both embraced the notion of depression as a unifying human emotion and related to him on a religious level. Because Tennyson's writing invokes melancholy and discusses mental illness, particularly depression, his poetry serves as unifying in the face of death. His understanding of his religion plays a similar role in unifying Victorian and modern readers alike with a common human emotion. This thesis ends with an analysis of The Prologue, which serves as the final admission of Tennyson's baptism of fire and how he is able to heal himself through the love and salvation of Christ. 


\section{PREFACE AND/OR ACKNOWLEDGEMENTS}

I would like to wholeheartedly thank Professor Summer Star for not only solidifying my passion for Victorian Literature and encouraging me to pursue my interest in mental illness in relation to Tennyson's poetry, but also taking on the responsibility of walking me through my Master's Thesis, which is no small feat. I would also like to thank Professor Sara Hackenberg and Professor Martha Klironomos for offering their assistance in such trying times. 


\section{TABLE OF CONTENTS}

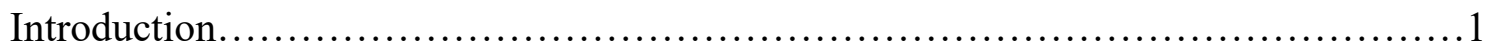

The Meaning of Melancholy and its Stigma in Victorian Literature (a short overview)..11 Melancholic Imagery: Landscapes of Decay and Desolation in Tennyson's Poesy......24

A Baptism of Fire: Sounding the Depths of Doubt and Faith in In Memoriam ...........47

Tennyson's Final Admission (The Prologue)...................................61

Conclusion............................................................... 73

Bibliography............................................................ 78 


\section{Introduction}

Throughout Alfred Lord Tennyson's large poetic corpus, there is no shortage of melancholic imagery. The Victorian poet's writing is exceedingly effective at illustrating melancholy, whether it is through powerful imagery (the black moss and the decrepit landscape in "Mariana" as well as the setting we find the Sleeping Beauty slumbering in, to name just a few), syllabic dexterity, diction, meter, etc.; but through his exploration of sorrow, grief, and religious doubt upon the death of Arthur Hallam in his elegy In Memoriam A.H.H., Tennyson is successful at reconfiguring his aesthetic of melancholy, manifesting his melancholy through his poetic writing, and ultimately finding meaning, whether it is through finding unity through a "common grief" with his fellow countrymen or through the period of self-reflection he experiences, drowning in doubt amidst his painful loss and grappling with his Christian faith.

Before his soul took the blow of suffocating grief, it seems as though Tennyson had already configured and consolidated the melancholic tone that blows life into his earlier works. Tennyson's knack for melancholic imagery is evident in many of his poems, including "The Lady of Shalott," the two "Mariana" poems, and "The Sleeping Beauty." While his beautiful control of poetic imagery is made clear in his more fantastical works, one has glimpses into his own profound knowledge of and ability to express his own experience with melancholy in In Memoriam. Though very different, in both his imaginative and raw, tender poems, the melancholy Tennyson's poesy so 
evidently exudes can be identified and felt through his extraordinary ability to write technically. In "The Lady of Shalott" (1833) for instance, Tennyson successfully sets up a plot riddled with heartbreak and isolation with a more romantic and less dreary backdrop. In this poem, Tennyson juxtaposes light with darkness, for even though the Lady of Shalott is confined to life in a tower watching the world through only a reflection and weaving what she sees, the landscape has luscious greenery, the sun "came dazzling thro' the leaves," and the bridle Lancelot uses rings "merrily" (line 75, 85). Tennyson combines the Romantic sublime in terms of unleashing the unbridled imagination, mysterious curses, colorful and lively representations of characters (Sir Lancelot's mesmerizing armor, for instance) and his melancholic shadow in his more fictitious poems, whereas in In Memoriam, raw melancholy dominates the narrative. Thus, it is clear that after Hallam's death, Tennyson reconfigured his perception and representation of melancholy in his poetry, which is the main thrust of my argument.

My overall argument that Tennyson's writing style changed while writing In Memoriam is multi-faceted, since the framework that goes into analyzing this reconfiguration depends on the exact details of the events surrounding this heartbreaking event and a solid representation and analysis of the aesthetic of his older pieces (which I discuss in Chapter II). The landscapes and character representations in Tennyson's earlier works are constructed differently than those in In Memoriam. One immediate example is that Tennyson was seemingly concerned with representing melancholy as it relates to the 
symbol of the forlorn woman and this cuts through much of his writing, which can be interpreted as Tennyson's own preoccupation with isolation and how he might relate to these characters. The concept of isolation paired with melancholic imagery and Tennyson's beautiful command of meter, diction, and syllabic dexterity is overall extremely effective in conveying his sorrow to his readers through the guise of both himself and a poet who speaks for the people, uniting them through a common human emotion. In his elegy, this changes, as we as readers now realize that at times (unlike "The Lady of Shalott," for example) Tennyson is both the speaker and the subject of In Memoriam. This is a significant shift in so many ways, as we are now connected to Tennyson because he bares his soul and allows his audience to become a part of the grieving process he endures. At one point, Tennyson further commented:

It is rather the cry of the whole human race than mine. In the poem altogether private grief swells out into thought of, and hope for, the whole world... 'I' is not always the author speaking of himself, but the voice of the human race speaking through him. ${ }^{1}$

This admission is interesting, as it allows his readers to determine in which cantos Tennyson is writing about himself versus those in which Tennyson is voicing humanity

\footnotetext{
${ }^{1}$ James Knowles, 'Remarks of Tennyson' in 'A Personal Reminiscence', The Nineteenth Century, XXXIII (January, 1893).
} 
as a whole. This aspect of Tennyson's mindset and goal in writing his elegy brings me to the historical context of In Memoriam which is germane to understanding the genuine lapse of faith Tennyson has in relation to his Victorian audience. In an age of new geological evidence contradicting the Christian church's timeline of Earth, Victorian society as a whole was going through a phase of doubt in solidarity with one another. In Memoriam confronts these doubts head on and serves as a unifying piece for Tennyson and his readers (both contemporary and Victorian), ultimately leading to Tennyson comfortably writing his elegy without fear of backlash from his community.

For four years Tennyson and Hallam's brotherhood blossomed and strengthened only to be cut short by the tragic tidings of Hallam's untimely death in far off Vienna. This was the turning point of the material and spiritual life of Tennyson and the death of his beloved friend wrought the Victorian poet's soul for many years to come, ultimately pinnacling at the seventeen-year mark in which the ink of In Memoriam was finally dried. Once Hallam died in his sleep an ocean away, Tennyson turned his back to his Christian faith, scrambling like a child "in doubt and fear" in a "Godless deep" who knows his father is near but not tangible. But, as writers do, Tennyson turned to the pen and sounded the depths of faith and doubt for seventeen years, weaving countless cantos together into one precise and final elegiac remembrance of Arthur Hallam. As one reads In Memoriam, it becomes clearer and clearer that those seventeen years of threnody, writing, and self-reflection were precisely reflective of how Tennyson's inner spirit was 
eventually guided back into the Lord's embrace. Where he once found God "not in world or sun/ Or eagle's wing, or insect's eye;/ Nor thro' the questions men may try...," he now takes solace in the fact that Hallam's soul is enshrined in heaven (CXXV, 5-6).

Tennyson explores his grief at the sudden loss of his friend, conveys the melancholy he endures through his writing, and navigates through his grief, digesting Hallam's death in tandem with his faith. Tennyson's poetry, then, guides him on a path to processing his friend's death, writing about it, while making an abundance of biblical allusions. Specifically, Tennyson's ability to portray his deceased friend as a Christ figure and his fixation on the notion of resurrection (both physical and spiritual) while turning to the story of Lazarus acts as Tennyson's Northern star throughout his reflection (as I will discuss in Chapter III). Tennyson's battle ultimately lies with spiritual immortality. Do souls live on after death? Is there an afterlife? These questions serve as the foundation for Tennyson's lapse in faith. Because Tennyson is ultimately able to transcend his grief and find solace in the salvation of Christ, the religious nature of the elegy provides meaning to the melancholy and, in In Memoriam's case, Tennyson's religious rhetoric and allusions allow him to transcend his grief and enshrine Hallam's memory in the written word while publicizing his spiritual odyssey and how he uses the duality between doubt and faith to navigate the grieving process.

Tennyson's melancholic poems draw not only upon the Victorian crisis of faith, but the Romantic crisis of personality as well, due to Tennyson's expression of his 
religious doubt while also losing himself in the process, only to find himself again when he finds his newfound faith. The crisis of personality I speak of lies in the overwhelming period of transformation Tennyson endured while he battles religious doubt, yearns for the nostalgia of his youth with Hallam, struggles with the disconnect from nature and God, as well as other stressors that forced Tennyson to reevaluate his life and reconfigure his personal beliefs and poetry accordingly.

Chapter I discusses the de-stigmatization of mental illness in Victorian culture which will provide information on the historical context of In Memoriam and how Victorian readers would have received it. This is a significant aspect of my overall argument, which is that In Memoriam was a text that united Tennyson with his readers. The expression of doubt and mental illness was not negatively received and thus serves as a cathartic experience for Tennyson, ultimately leading to him finally finding comfort in his faith and fellow man. New scientific discoveries that contradicted the church's timeline of the earth, for instance, caused many Victorians to doubt the religion they had once believed in wholeheartedly. In Memoriam speaks to such an audience, which ultimately unites Tennyson and his readers in a religious context as well an emotional context in relation to grief. In this chapter, I draw on many scholars such as Ann Colley and her book, Tennyson and Madness, David Riede's Allegories of One's Own Mind: Melancholy in Victorian Poetry, and Vineta Colby's article Browning's “'Saul': The Exorcism of Romantic Melancholy," each of which delve into psychological 
investigations of Tennyson and his Victorian contemporaries and how they perceived mental illness. Scholars such as these help my argument in that there is a clear consensus that Tennyson was a poet of melancholic sensation and mental illness was a common discourse in Victorian society; thus, In Memoriam serves as a piece that was of great interest to Tennyson's audience.

Next, I move on to my second chapter entitled "Melancholic Imagery: Landscapes of Decay and Desolation in Tennyson's Poesy," which details Tennyson's writing aesthetic in relation to melancholy and how, I feel, his earlier work is grounded in melancholy. It is here that I will analyze some of his early works to familiarize my readers with Tennyson's original aesthetic. This is be crucial to understanding how Tennyson's overall aesthetic was reconfigured upon the passing of Arthur Hallam and put to work in his elegy In Memoriam, and will help my readers understand that the language Tennyson uses in his work is not the only factor of his aesthetic; the settings he constructs in his poetry are also crucial aspects of his work when considering melancholy and how Tennyson uses this aesthetic in multifaceted ways. I juxtapose the romantic landscapes of Tennyson's earlier works with the dark landscapes we see in In Memoriam as well as point out that Tennyson has a clear relationship with his Romantic forbears, and represents a struggle between man and nature, an aspect that particularly shines when Tennyson details the vessel carrying Hallam's body back to England, and how he worries the force of the ocean will be too fierce and his beloved friend will be possessed and 
taken by the water, failing to deliver his body safely. This is crucial, because as we will see in Chapter I, Tennyson was somewhat influenced by his Romantic predecessors and we see this in particular parts of the elegy. To help my argument, I engage with scholars such as Henry Van Dyke, who alludes to the many forlorn women in Tennyson's earlier works, and how in In Memoriam, there are many moments where Tennyson seems to identify with these women, even comparing himself to a widow several times. Furthermore, in his article "Tennyson and the Measure of Doom," Herbert F. Tucker discusses the relationship of sound and image and how Tennyson draws upon both in his poetry (this comes into play when we discuss the brutality of nature and how Tennyson represents such cruel forces). Where in his earlier works man and nature seem to be united, In Memoriam tells a different tale and there is a clear shift in Tennyson's outlook on nature and its relationship to God to his disillusionment with both, which in turn provides a testament to his disconnect from his religious faith.

My third chapter entitled "A Baptism of Fire: Sounding the Depths of Doubt and Faith in In Memoriam” explores Tennyson's abundance of biblical allusions in his elegy and how they contribute to the overall expression of Tennyson's grief as well as how intense the initial religious doubt he experienced after his friend's passing was. This chapter introduces Tennyson's faith in relation to his poetry, where I now focus solely on In Memoriam. However, this chapter focuses on doubt and doubt alone; the conclusion of my thesis is where I discuss Tennyson's reunion with his religious faith. Tennyson 
invokes the story of Lazarus, for instance, whom Tennyson is fixated on, yearning for an explanation of what Lazarus saw after he died before being resurrected by Christ.

Allusions such as this represent Tennyson's initial grief. I will draw on critics such as John D. Rosenberg, who makes many insightful comments and draws connections to the language Tennyson uses in In Memoriam and how there are many biblical undertones. After the death of Hallam, Tennyson notably loses his faith and spirals into a whirlpool of doubt, leading him into becoming a melancholiac and succumbing to the mental illness so prevalent in his family line. We as readers now see that Tennyson is both the subject and speaker at times, an important observation when comparing his elegy with a poem such as "The Sleeping Beauty."

Lastly, Chapter IV entitled “Tennyson's Final Admission (The Prologue)” reveals the culmination of the seventeen-year writing process Tennyson was entrenched in. In Chapter III I invoke all of Tennyson's biblical allusions as they pertain to doubt, while in my conclusion, I reference religious allusions Tennyson makes in relation to his newfound faith, specifically how Tennyson relates Hallam to Christ and how this connection might have brought the poet comfort. Tennyson's portrayal of Hallam as a Christ figure is not the only facet of this chapter, though. In the Prologue, Tennyson declares his newfound faith and accepts that "We have but faith; we cannot know" (21). He accepts that blind faith is what we have but that it can sustain his religious beliefs and he begs forgiveness for ever doubting his Heavenly Father. In this chapter I cite scholars 
such as John Rosenberg, who wrote "Idylls of the King: Evolving the Form" as well as “The Two Kingdoms of 'In Memoriam.” In addition, Tyler Tichelaar's article, “Christ, King Arthur, and Arthur Henry Hallam in Tennyson's Idylls of the King" is an exceedingly helpful text in making correlations between Hallam and Christ. I detail Tennyson's final epiphany that he has faith in Christ once more by detailing moments in In Memoriam where Tennyson writes Hallam as a Christ figure, and how this ultimately leads Tennyson back to the "Strong Son of God, immortal Love,/ Whom we, that have not seen thy face,/ By faith, and faith alone, embrace..." (I. 1-3). 


\section{CHAPTER I}

\section{The Meaning of Melancholy and its Stigma in Victorian Literature (a short overview)}

Tennyson's writing attracts a variety of opinions, both contemporary and Victorian. Though his other works have invited an abundance of scholarly discourse, none have been as widely discussed as his elegiac masterpiece, In Memoriam. Through his exploration of loss and religion in this long poem, Tennyson is successful at manifesting his grief through his poetic writing and ultimately finding closure, whether it is through the unity of a "common grief" or through the period of self-reflection he experiences, drowning in doubt and grappling with his Christian faith. This, too, is why Tennyson's elegy was a success, in that it discusses grief, melancholy, and a crisis of religious faith, aspects of Victorian life that many would have found unifying. Both positive and negative, the criticism this poem has enticed since its publication in the years 1850 and 1855 is vast. Critics of Tennyson's time engaged in discussion about his religious rhetoric, the doubt he feels amongst his faith, and the concept of death. George Eliot once observed: "Whatever was the immediate prompting of In Memoriam, whatever the form under which the author represented his aim to himself, the deepest significance of the poem is the sanctification of human love as a religion." 2 The central questions or

2 Westminster Review, October 1855, p. 191. Cited by Stephanie Forward in her article, "In Memoriam A.H.H.: Composition and Reception" 
themes this poem poses and enshrines at its core are melancholy and the duality of faith and doubt, specifically in Christianity and Jesus Christ, whom Tennyson directly addresses in The Prologue. Since its inception, critics were drawn to this poem in particular because of the magnitude of the work as well as the religious nature of the Victorian audience.

In Memoriam is a poem that explores mental illness, loss and subsequent grief, religious doubt, and faith. To effectively explore Tennyson's self-reflective and melancholic writing, it is important to frame it with the historical context in which he was writing and how his audience would have received his interpretation of melancholy and religious doubt. The Victorian era was a time of innovation and growth, introducing industrial inventions, railway constructions, scientific discoveries, higher education for women, and other monumental changes. From this spawned great debates, as contradictory evidence began to cause an overwhelming upset in the Victorian era's immensely religious society. Charles Darwin's The Origin of Species, for instance, was one such text that contradicted the church's timeline of the earth and challenged the people's religious beliefs, resulting in bouts of religious doubt. Before Darwin, however, came his forbears such as Charles Lyell (1830) who acknowledged the gradual change of the earth and its climate over very long periods of time as well as attempted to bridge the 
gap and reconcile religion with evolutionary theory. Robert Chambers, in his book Vestiges of the Natural History of Creation, discusses geology in relation to recent scientific discoveries: "Geology fully proves that organic creation passed through series of stages before the highest vegetable and animal forms appeared" (Chambers, 31).

Because science and religion played such vital roles in Victorian society, it is clear how such scientific and geological innovations greatly interrupted the status quo, resulting in the Victorian crisis of faith. In his book The Victorian Temper: A Study in Literary Culture, Jerome Buckley writes: "The Victorians, we are told, were a 'poor, blind, complacent people;' yet they were torn by doubt, spiritually bewildered, lost in a troubled universe" (Buckley 2). The Church was unable to console its members at a time when people needed much stability and reassurance because they became entrenched in debates on geological timetables and evolutionary enlightenment. This crisis of faith was reflected in much of the literature written in the $19^{\text {th }}$ century. Gerard Manley Hopkins, for example, wrote his poem "God's Grandeur" to comment on such a crisis and offers hope to his audience. Matthew Arnold, too, wrote his poem "Dover Beach," which expresses the diminished stance of Christianity and how the speaker cannot see a way the faith will withstand the rising tide of scientific discovery. Tennyson's In Memoriam fits perfectly into this literary niche as well. While Tennyson does not only refer to such scientific advancements, he also expresses melancholy, sorrow at the loss of his beloved friend, 
religious doubt, as well as his newfound faith at the end of his spiritual journey. In essence, In Memoriam greatly expressed the mood of the Victorian age.

As Tennyson is quoted as having said in his 1897 Memoir: "I am black-blooded like all the Tennysons. I remember all the malignant things said against me, but little of the praise." This Tennysonian self-awareness, that of recognizing his melancholic writing and his contemporaries engaging in criticism of his work, and only processing the negative opinions shows a distinct consciousness of his vulnerability to succumb to the mental illness in his family line and how they relate to his poetry. But where did this awareness originate and how did it manifest in Tennyson's work? Arthur Hallam, before his untimely death, explored this question, touching on the relationship between the Victorians and the Romantics, and how Tennyson's poetry "so evidently characterizes the spirit of modern poetry." ${ }^{3}$ So what did Tennyson adopt from his Romantic predecessors? And how did his unique writing style fare with his Victorian audience? In his book The Poetry of Experience, Robert Langbaum states "the romantic quality of mind grows out of a total crisis of personality" (Langbaum, 29). One example of the poetry of this "crisis

\footnotetext{
${ }^{3}$ Quoted in David Riede's “Tennyson's Poetics of Melancholy and the Imperial Imagination," page 659.

Quoted from Arthur Hallam, "On Some of the Characteristics of Modern Poetry, and on the Lyrical Poems of Alfred Tennyson," in The Writings of Arthur Hallam, ed. T. H. Vail Motter (New York: Modern Language Association of America, 1943), pp. 182-98.
} 
of personality" is Wordsworth's The Prelude, a text that is dominantly known for chronicling the poet's journey from childhood to adulthood, finding himself and his place in the universe. The coincidence that the final edition was published in the same year as In Memoriam, I believe, is a testimony to other facets Tennyson and his predecessors have in common. For one, these texts both spring from each author's deep-rooted selfanalysis. But Tennyson separates his work from his Romantic forbears in a way that is unique to him. While Wordsworth and his contemporaries investigated and intertwined their writing with nature, supernaturalism, and other forces in the universe that were common to the Romantics, Tennyson grapples with such existential threats out of loss and sadness, rather than the prompting of curiosity or faith. However, In Memoriam does respond to the mood of the Victorian age by publicly responding to the Victorian crisis of faith as well as the Romantic crisis of personality.

In addition, Tennyson's disposition toward nature in his poetry, specifically in In Memoriam, is hard to parse in a singular way. His elegy represents a larger struggle, not only between Tennyson and his grief, but between Tennyson and nature, which manifests itself through the poem's religious rhetoric. It seems as though Tennyson lacked consolation from nature and God when Arthur Hallam passed away. Out of this struggle springs the "crisis of personality," to use Langbaum's term, which is a clear theme of In Memoriam, and one that I will thoroughly investigate in the chapters to come. While the 
Romantics encouraged unleashing the wildness of the sublime, the Victorians preferred to not have such untamed expressions of the human psyche inserted into the landscape of poetry. ${ }^{4}$ In her book Tennyson and Madness, Ann Colley aptly asserts,

The impetus, though for this [crisis of personality] did not come from Tennyson alone. It also belonged to the mood of his age, which feared the excesses of the Romantics and, therefore, anxiously explored the darkness, using analytical and clinical tools. The Victorians did not want to become victims of that darkness and believed that one way to overcome such a fate was to attempt to understand, to shed light on the misery and pain. (Colley, 8)

Shedding light on these psychological traumas came with a hitch, though. Melancholy was to be expressed and not glorified, due to the Victorians' tired attitude toward the Romantics' overuse of melancholic undertones in literature. Tennyson's poetry seems to strike a balance between the two. There is a clear interest and willingness to explore the merging of poetry with what Ekbert Fass, in his book Retreat into the Mind: Victorian Poetry and the Rise of Psychiatry, terms "mental science" (Fass, 47). Colley agrees with this notion, while also stating that Tennyson's poems "reflect his lifelong struggle to

${ }^{4}$ David Riede, in his book Allegories of the Mind, makes the distinction that the late Romantics viewed melancholy as a symptom of "genus," while the Victorians directly correlated melancholy and its expression in literature with depression. 
avoid madness by observing and mastering its manifestations" (Colley, 1). Similarly, other scholars have made the assertion that Tennyson feared the concept of the "black blood" of the Tennysons, and thus spent "many hours and many verses in brooding on whether madness and melancholia were hereditary" (Ricks, 56). ${ }^{5}$ We see this exact anxiety in his earlier works, before he succumbed to a depression in 1833, the day "That in Vienna's fatal walls/ God's finger touch'd [Arthur Hallam], and he slept" (LXXXV. 1920). "The Lady of Shalott," for example, reflects this anxiety, as we see the Lady succumbing to the mysterious curse, floating down the river reminiscent of blood, slowly freezing, and taking on dark physical features in the process. Mariana, too, displays symptoms of a melancholiac, surrounded by an environment immersed in darkness and decay. In Memoriam is similar in nature. We see Tennyson succumb to the abyss of sorrow, something he and his contemporaries actively tried to avoid.

According to Vineta Colby in her article "Browning's 'Saul': The Exorcism of Romantic Melancholy," "melancholy — a state of mind that Victorians publicly deplored as self-indulgence nevertheless remained precious simply as it reflected that 'higher' element, the capacity to feel... and acknowledge one's participation in the emotions shared by all mankind" (Colby, 88). The basic expression of grief, loss, or depression was

${ }^{5}$ Ricks, Christopher. Tennyson. New York: The Macmillan Company, 1972. 
nothing to be ashamed of and writing about it could be seen as unifying to Tennyson and his readers. After its final publication, In Memoriam deeply resonated with his audience, and the unity of religion and its role in manifesting grief in Victorian society can be summed up in one major way: when Prince Albert died in 1861, 11 years after Tennyson's elegy was first published, the whole country mourned with Queen Victoria. She kept a copy of In Memoriam by her bedside and called it her second comfort next to the Bible, noting in her journal entry for January 5, 1862 that she was "Much soothed and pleased with Tennyson's In Memoriam. Only those who have suffered as [she did] can

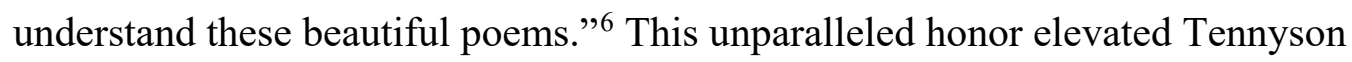
significantly and certainly legitimized his work both as a poet and as a man stricken with grief with the beautiful ability of manifesting it into words that help soothe his audience. In his book Tennyson: To Strive, To Seek, To Find, John Batchelor elaborates on Tennyson's intimate relationship with Queen Victoria and how the two found common ground with their grief. When Tennyson visited her in 1862, "the theme of bereavement provided rewarding common ground for these two self-centered personalities" (Batchelor, 6). After their meeting, Queen Victoria wrote in her diary "I told him how much I adored his glorious lines to my precious Albert [the new dedication to the Idylls]

\footnotetext{
${ }^{6}$ Cited by Stephanie Forward in her article, "In Memoriam A.H.H. by Alfred Lord Tennyson"
} 
and how much comfort I found in his In Memoriam. He was full of unbounded appreciation of beloved Albert. When we spoke of my own loss, of that to the Nation, his eyes quite filled with tears" (Batchelor, 6-7). These lines express with great clarity how emotionally connected Tennyson and Queen Victoria were in relation to mourning. Queen Victoria mentioning “the Nation” as well as Tennyson's emotional response to their conversation furthers the notion that grief can be a unifying emotion and that his writing had the power to soothe those who have experienced grief and those who are experiencing grief together. However, they not only spoke of In Memoriam, but "Mariana" as well due to the fact that Queen Victoria stated "I am like your Mariana now" (Batchelor, 7). This is a significant insight, in that a figure such as Queen Victoria aligning herself with one of Tennyson's most helpless, forlorn characters furthers the notion that Tennyson's poetry, though sometimes fanciful, accurately represents and speaks to those who experience sadness, grief, and other distressed states of the mind.

Tennyson expresses this notion of unity in grief in the lines "One writes, that..../That 'Loss is common to the race'_/And common is the commonplace,/ And vacant chaff well meant for grain;" however, Tennyson is still able to differentiate his own personal grief when he writes "That loss is common would not make/ My own less bitter, rather more:/ Too common! Never morning wore/ To evening, but some heart did break" (VI.1-8). In this way, Tennyson both acknowledges the grief his fellow man experiences whilst also isolating his own grief and how this commonality does not 
console him. However, this canto is placed in the beginning of the elegy where the sting of his grief was at its peak. Later in the elegy, Tennyson moves away from this notion and begins to accept Hallam's death in relation to commonplace human emotions. Coming from a family plagued with mental illnesses, Tennyson had an alcoholic father, an institutionalized brother, and his own acquaintance with death and grief through not only the loss of his stillborn son but also his best friend, a strife that would be uniquely suited for poetic expression. In his book Allegories of One's Own Mind: Melancholy in Victorian Poetry, David G. Riede makes the astute claim that Victorians "often saw melancholy as we now see depression, as a mute or incoherent mood that imprisons the sufferer within himself and the precise antithesis of poetic creativity" (Riede, 2). In addition, although depressive states are incredibly debilitating to one's state of mind, ironically, "the Victorian melancholy turns out to be poetically productive rather than disabling" (Riede, 2). As we will see, Tennyson's cathartic experience in writing his elegy to cope with his grief speaks to just how accurate Riede's assertion is. Colby further states, "Tennyson did not ignore the dark side of humanity" (Colby, 90). Tennyson is a poet of melancholic sensation and does not hold back in expressing it, his written works being grounded in melancholy and his "preoccupation with certain emotional qualities that the Victorians especially cherished — melancholy among themrightly or wrongly made him the most highly esteemed poet of the century" (Colby, 99). This human emotion paired with a Christian audience made for a unifying poem. In his 
article “Tennyson's Poetics of Melancholy and the Imperial Imagination,” David G. Riede articulates that many scholars seem to agree that Tennyson's "melancholy expresses an erotic blend of pain and pleasure" and is generally thought a primary characteristic of Tennyson's “essential genius" (Riede, 660-662). Essentially, his poetry is the epitome of natural, human emotion and therefore acts as a unifying catalyst to the “common race.” Melancholy paired with religion represents (in Tennyson's work) the capacity to feel natural human emotions and the unifying aspect of grief in the Victorian era. In these lines_- " 'Loss is common to the race'_/And common is the commonplace"- Tennyson gives his elegy to the public, a symbol of unity, even though Tennyson at first expresses he feels there is a distinct difference between his grief and the grief of others (VI. 2-3). The haunting presence of the black blood of the Tennysons is apt in this stanza due to the fact that Tennyson feels his loss is not commonplace ("That loss is common would not make/ My own less bitter, rather more") (VI. 5-6). There is a keen sting that Tennyson feels separates his loss from the rest, giving him a sense of isolation. Though he ultimately finds comfort through publicizing his spiritual odyssey, Tennyson's grief comes in waves. And so, navigating back and forth from hope and despair, solidarity and isolation, melancholy and meaning, Tennyson explores his faith.

The concept of Tennyson making an abundance of biblical allusions throughout In Memoriam helps unite his readers as well; death and grief is not the only human 
experience Tennyson draws upon in writing his elegy. In Faith and Doubt in the Century's Poets, Richard Armstrong makes the insightful observation that Tennyson "recognized the fact that [a biblical] allusion wins half its power from its connection with the readers' memory and previous thought...In order to be forcible and effective, it must be at least so familiar as to awaken a train of associations" (Armstrong, 25). Whether or not he knew the implications of using religion as a rhetoric and to reflect on his loss while writing his elegy, Tennyson was outspoken about his work and acknowledged that this poem was both within and without him ("It is rather the cry of the whole human race than mine and 'I' is not always the author speaking of himself, but the voice of the human race speaking through him"). Religion and loss united his Victorian readers; this, Tennyson must have known when he agreed to have his elegy published. In this highly insightful assertion, Tennyson admits he wrote In Memoriam sometimes under the guise of a poet who speaks for the people. Though death will always be a shared, human experience, In Memoriam was written in a time where the public needed a helping hand. The Victorian crisis of faith and other cultural changes created an opening for Tennyson's elegy to insert itself into society to offer comfort and solace to an audience going through similar motions with one another. In this poem, Tennyson contends with the many phases of grief and portrays the extent of his loss in a way that takes his readership on the same journey he was on. His brilliance, connection to the Romantics, and his personalized aesthetic in combining Romantic and Victorian ideals in relation to 
his poetry bridges the gap between his Victorian readers and his writing by expressing common human emotions and struggles such as loss and the duality of faith and doubt, an aspect highly praised by his contemporaries. As I stated in the introduction, Tennyson's melancholic aesthetic changed after the death of Arthur Hallam, and I explore his aesthetic both before and after the death of Hallam in the next chapter. 


\section{CHAPTER II}

\section{Melancholic Imagery: Landscapes of Decay and Desolation in Tennyson's Poesy}

As readers become more familiar with Alfred Lord Tennyson's large poetic oeuvre, it becomes clear that the landscapes, characters, and places he imagines in his pieces, both fictitious poems like "The Lady of Shalott" and more realistic ones like In Memoriam, play a significant role in creating the melancholic aesthetic that precisely makes Tennyson's work his. Both Victorian and contemporary critics such as David Riede in his article, "Tennyson's Poetics of Melancholy and the Imperial Imagination," "have recognized that Tennyson's early work attempts to establish a kind of poetic authority, and that its characteristic power is grounded in melancholy" (Riede, 659). Riede is right in his assertion that the large majority of Tennyson's work has melancholic undertones. However, Tennyson's remarkable ability at working with diction, meter, syntax, and figurative language can, for those who look closely, reveal a shift from Tennyson's representation of romantic melancholy in his earlier works into the kind of melancholy that one can find meaning in, ultimately transcending the bonds of grief rather than simply expressing grief with no resolution. In Memoriam accomplishes this feat, as Tennyson is able to peel back multiple layers of grief and turn "a poetics of melancholy [into] 'the royal way through which humanity transcends the grief' of separation from a supposed lost wholeness of being" (Riede, 659). This is just one major aspect of Tennyson's aesthetic reconfiguration after the passing of Arthur Hallam. 
Though Tennyson demonstrates a familiarity with romantic melancholy in his enchanting, fanciful works, In Memoriam's earlier cantos express with greater effect Tennyson's navigation through the immediate emotions of a sudden loss and grief, and therefore, "images of darkness and death are [immediately] forced upon us" (Rosenberg, 229). In Memoriam is tangible in a way that "The Lady of Shalott" or "Mariana" are not. Not every reader is a forlorn woman, yet readers can empathize with a "widow'd" heart. No more are there glistening bridles, fields of flowers, and shiny gems, reminiscent of Wordsworth and his contemporaries. They are replaced with rain, skies of black, and an empty, godless void in which Tennyson and the speaker of In Memoriam find themselves trapped. Because of the autobiographical nature of Tennyson's elegy, it is not only grounded in melancholy, but reality as well. So, moving forward, as we analyze the landscapes Tennyson constructs, an understanding of Tennyson's old melancholic aesthetic and what the word melancholy connotes is imperative to understanding his shift in aesthetic upon writing his magnum opus, In Memoriam.

The word "melancholy" itself derives from the medieval concept of black bile or black blood as part of the concept of the four humours, which suggested that the presence of such fluids were indicators of depression. ${ }^{7}$ The theory was thrown out by the $19^{\text {th }}$

${ }^{7}$ Jackson, Stanley W. Melancholia and depression: From Hippocratic Times to Modern Times. Yale University Press, 1986. 
century, yet the etymology of the color black lingers in relation to melancholy, so it is fitting that Tennyson uses the color black in his poems to convey the darkness of the landscapes and plots he writes into existence. When reading Tennyson's earlier poems such as "Mariana," images of darkness, specifically the color black, are immediately thrust upon readers as Tennyson first sets up the scenic backdrops his fictional characters dwell in. ${ }^{8}$ In "Mariana," for example, the landscape Tennyson places her in is decrepit and desolate. By presenting the house's interior as a direct reflection of the state of Mariana's mind and not just her environment, Tennyson uses the color black and other dark hues in this poem to contribute to the representation of Mariana's psyche significantly. The moated grange in which forlorn Mariana paces has "blackest moss" on flower-plots and looms under the "thickest dark [that] trance[d] the sky" (1-13). Rusted nails litter the property, broken sheds look "sad and strange," the wind is shrill and cold, and the sky is gray (5). The black moss and the other battered and broken elements surrounding the house are a significant representation of the melancholy this landscape exudes. Mariana's repeated, if varying, lament of "'The night is dreary,/ He cometh not,' she said;/ She said I am aweary, aweary,/ I would that I were dead!'” contributes to the overall atmosphere Tennyson created to direct his readers' gaze not only toward

\footnotetext{
${ }^{8}$ While the color black is hueless, darkness has a relative lack of light, and contributes to the same aesthetic; for the purpose of my argument, I find them relatively interchangeable.
} 
Mariana's environment, but into the mind of melancholic Mariana as well (9-12). After we are aware of the condition of the outside of the house, the speaker leads the reader into the interior of the house and thus metaphorically into the mind of the melancholic patient. Unlike the speaker of In Memoriam, the repetition of Mariana's lament that she is dreary and aweary hints that poor, distressed Mariana has no chance of escaping her mental shackles and there is a lack of resolution because the speaker does not offer one. In contrast, though we follow the speaker of In Memoriam through phases of confusion and grief, Tennyson is able to manifest his melancholy into a stronger relationship with his religious faith and escape his melancholy. This is the first notable aspect of Tennyson's aesthetic transition.

The 1833 edition of "The Lady of Shalott" is both similar and different in this regard. Just as in "Mariana," Tennyson inserts much detail into the landscape, but where the house in Mariana is broken and decayed, the atmosphere he creates in "The Lady of Shalott" is more faithful to the Romantic sublime, for even though the Lady of Shalott is confined to life in a tower, watching the world through only a reflection and weaving what she sees, the landscape has luscious greenery; the tower the Lady of Shalott labors away in "overlook[s] a space of flowers," "a pearl garland winds her head," the sun “came dazzling thro' the leaves," and the bridle Lancelot uses rings "merrily" (lines 16, 33, 75, 85). "The Lady of Shalott," too, explores similar themes of isolation, heartbreak, love sickness, and romance, yet the imagery Tennyson conveys in this particular poem 
represents the romantic sublime and is much less dreary than that of "Mariana." Tennyson is still able to set up a romantic backdrop whilst also carrying forward a heartbreaking plot rife with melancholic imagery, diction, and dialogue. Images of flowers, gems, yellow fields, crystal mirrors, etc. create the lustrous scenery of a story riddled with melancholy. Tennyson's faithfulness to the Romantics and melancholy is perfectly encapsulated in his description of Lancelot. ${ }^{9}$ The illustration of Lancelot in this poem can be overwhelming at times; it is clear that Tennyson is intentionally turning his readers' gaze to the knight's spectacular appearance with the help of the enchanted backdrop behind him—essentially, Lancelot becomes the focal image for a good portion of the poem as a whole. Lancelot's shield "sparkle[s] on the yellow field," and his horse's bridle is encrusted with gems and gleams in the sunlight like "some branch of stars we see/ Hung in the golden Galaxy" (80-84). His description bedazzles the eye of the reader and suggests that the only darkness in this poem is that of the mysterious curse upon the Lady of Shalott, ready to strike once she gazes out of the window and the mirror shatters. But, taking a closer look, the melancholic aesthetic exemplified in "Mariana" endures here, too, for Tennyson does employ the color black, just not how one might expect. He writes, "From underneath his helmet flow'd/ His coal-black curls as on he rode" (105106). This is a significant detail, as it both reconfirms Tennyson's poetic rhetoric of 
melancholy (that he will eventually reinforce much later in In Memoriam) and reiterates the color black and its scientific relationship with melancholy. As a twelfth century document notes, "Melancholiacs show the same color of the head, face, and eyes and the same blackness and thickness of hair and face." ${ }^{10}$ Therefore, though subtle, it seems as if Tennyson inserted this detail as an ode to the color that epitomizes melancholy. Similarly, in his poem “The Sleeping Beauty," Tennyson's use of words such as "the slumberous light is rich and warm" and "with bracelets of the diamond bright" connote yet another beautiful scenery rich with color and hints of magic to narrate a story about another damsel with a "charmed heart" doomed to a life of isolation (7-20). But, much like "The Lady of Shalott," Tennyson strategically places the color black into her environment, for the sleeping beauty is beautiful but cursed, and her "full black ringlets" are a major indicator of the melancholy this curse has brought upon her as well as sets up the juxtaposition between light and dark in the poem (12). This is not to say that all mention of the color black, no matter the context, is a symbol of melancholy. However, because the color black is an established part of Tennyson's melancholic aesthetic, he provides a direct link between the physical traits of those prone to melancholy and Sir

\footnotetext{
${ }^{10}$ Stanley W. Jackson, Melancholia and Depression: From Hippocratic Times to Modern Times. (Yale University Press, 1986), 77.
} 
Lancelot, the landscape in "Mariana," and the Sleeping Beauty. Not only is his black hair his only dark quality, Lancelot's appearance is what prompts the Lady of Shalott to leave the tower. Though he has a mesmerizing, colorful appearance, his black hair, a small and easily overlooked detail, is significant, for Sir Lancelot is the final image she sees before she triggers the prophetic curse which will ultimately take her life: "From underneath his helmet flow'd / His coal-black curls as on he rode,/ As he rode down from Camelot./ From the bank and from the river/ He flash'd into the crystal mirror, / 'Tirra lirra, tirra lirra:'/ Sang Sir Lancelot" (102-108). It is after her gazing at him that "She left the web, she left the loom," and continues on to her death, gaining dark attributes in the process (“her eyes were darken'd wholly") (108-110; 158).

The ending of the "The Lady of Shalott" is bittersweet, though. The Lady of Shalott dies, but her death is recognized by society. In the 1833 version, she is looked down upon by "Knight, minstrel, abbot, squire, and guest" who "cross'd themselves, their stars they blest," and in the 1842 version, Lancelot looks at her and muses, "She has a lovely face;/ God in his mercy lend her grace,/ The Lady of Shalott" (193-194; 203-205). In the first edition, the citizens of Camelot gather around the vessel carrying The Lady's lifeless body, confused. The piece of parchment placed on her breast gives them only an idea of who she was. In the 1842 edition, Lancelot acknowledges her death though also only focuses on her beauty. While the 1833 version allows the Lady of Shalott to share her story with the citizens of Camelot in the form of the parchment, so as to not die 
unknown and forgotten, the beginning lines of the last stanza in the 1842 version create a more chaotic scene: "Who is this? and what is here?/ And in the lighted palace near/ Died the sound of royal cheer;/ And they cross'd themselves for fear" (163-166). After this though, Sir Lancelot addresses her directly, and though his comment may be superficial, the Lady of Shalott "hath no loyal knight and true," and Lancelot's comment resonates with this fact, perhaps giving a taste of what The Lady of Shalott could have had without the curse (62).

In Memoriam is again both similar and different. The legacy of Hallam was recognized by Victorian society, but the difference between Hallam (as a historical subject) and the Lady of Shalott (as a fictional character) is that Tennyson was so changed by Hallam's death that he wrote his most memorable work, while the Lady of Shalott did not leave behind a loved one who could memorialize her death. The Lady is not truly recognized as a person but merely just a beautiful face. Hallam, as the subject of In Memoriam, is represented to the fullest extent, not just by looks but by his great achievements and personality as well. This representation of Hallam leads to multiple conclusions: his legacy is now enshrined in the written word, Tennyson's grief is partially relieved by the poetic process in which he wrote In Memoriam, and the magnitude of the elegy corrects the brevity Lancelot displays. Essentially, we are now seeing a shift in Tennyson's narrative in that there is now resolution. 
The rhyme scheme and meter in "The Lady of Shalott," just like "The Sleeping Beauty" and "Mariana," does not stray too far off of iambic tetrameter and trochaic tetrameter, and each stanza ends with "Shalott," "Camelot," or "Lancelot." "Mariana" accomplishes a similar feat of repetition as each stanza but the last ends with "She said, 'I am aweary, aweary, / I would that I were dead!"” (the last stanza reads "'She wept, 'I am aweary, aweary,/ Oh God, that I were dead!'”) (11-12; 83-84). The repetitiveness of the rhyme scheme and meter illustrates the cyclicality of melancholy and the Lady of Shalott laboring away day after day as well as Mariana's endless pacing and lament. Not only does the imagery illustrate the isolation felt within the poem, but because of the consistency of the rhyme and meter, one can also visualize and hear the repetitious nature of the Lady's and Mariana's daily life by reading it aloud or silently. A person with melancholy or depression does feel an aspect of being trapped in their own head and the isolation of the female characters that Tennyson represents is a perceptive connection to melancholy in reality versus fiction, yet Tennyson is still able to romanticize and intertwine it with the sublime with the words and backdrops he chooses, a facet he does not include in his elegy. ${ }^{11}$ In his book Beach's Family Physician (1861), Dr. Wooster Beach describes symptoms of melancholy that mirror Tennyson's concept of repetition, isolation, and entrapment: "the patient afflicted with melancholy shunned society and

${ }^{11}$ In this instance, I mean Romantic as in the romantic sublime. 
courted solitude, was fearful and low spirited, and indulged in a certain train of thoughts upon one subject" and this subject was generally "that which was the cause of his misfortune." While Mariana dwells upon her heartache in a series of repetitive laments, seemingly unable to leave the property she is pacing in, "The Lady of Shalott" also expresses repetition in each stanza that mirrors the repetitive actions the Lady of Shalott participates in day in a day out, also trapped inside literally and metaphorically, as she dies upon breaking her isolation and making contact with the outside world. This is but a taste of Tennyson's original aesthetic but, I feel, a fair representation of his earlier works.

As for the characters in his work, Tennyson has a deep focus on isolated, love sick women at the center of his poems (Mariana, Sleeping Beauty, etc.). In his article “The 'Fatal Woman' Symbol in Tennyson,” Clyde de L. Ryals acknowledges Tennyson's deep focus with this type of woman at the center of his works and states, "since the figure of the beguiling maiden recurs with such persistency in Tennyson's early work, we are, almost inevitably, led to assume that it possesses some symbolic value" (de L. Ryals, 441). Because his other works represent this archetypal character frequently, it is no surprise that in In Memoriam, Tennyson still does not deviate from this and astonishingly compares himself to a "fatal woman" through the allegory of a widow many times ("In words, like [widow's] weeds, I'll wrap me o'er"), and later in the elegy writes "My heart, tho' widow'd, may not rest" as well as "Tears of the widower, when he sees/ A late-lost form that sleep reveals, / And moves his doubtful arms, and feels/ Her place is empty, fall 
like these" (XIII, 1-4). Here, not only does he compare himself allegorically to a widower, he takes it one step further by yearning for a late wife to return to bed rather than a husband. I can't help but notice Tennyson's shift from the widow to the widower. It seems, for Tennyson, gender is interchangeable when it comes to comparing Hallam's death to the death of a spouse. He continues to lament, "So find I every pleasant spot/ In which we two were wont to meet,/ The field, the chamber, and the street,/ For all is dark where thou art not" (VIII. 9-12). Here, Tennyson is still grasping at any chance he can get to feel his beloved Hallam's presence again while also reinforcing that darkness has taken over his life. In his book, Studies in Tennyson, Henry Van Dyke declared, "Their minds and hearts were wedded in a friendship which was closer than brotherhood, ... so that Tennyson spoke of himself as 'widowed' by the loss" (Van Dyke, 107). Throughout In Memoriam, there are many instances where Tennyson yearns for Hallam's touch and embrace as well as referring to himself as both a male and female widow. In his article "In Memoriam and the Extinction of the Homosexual," Jeff Nunokawa asserts that Tennyson's bride is a "metonym for the loss of Hallam" and the gender anxiety we see in the elegy further underscores the notion of how intimate Hallam's and Tennyson's friendship was (Nunokawa, 429). The emphasis on Tennyson's "bride” throughout the elegy expresses with greater affect how the death of Hallam haunted him and catalyzed the shift in Tennyson's melancholic aesthetic (much more than what a platonic dynamic would have contributed). 
The fictional atmospheres Tennyson creates in his poetry reflect an understanding of the word and meaning of melancholy so deeply that his words hold the wondrous power of leaving a reader truly feeling their own form of loss and grief, even if it's for Tennyson's sake. Though there is something to be said about close-reading his imagery and approach in his fictional poems and how they might parallel to Tennyson's own life and feelings, when Tennyson manifested his own grief in In Memoriam, a much less fanciful poem, he is still able to deliver the same effect of melancholia through the technical accomplishments as well as the imagery he creates. However, there is a fairly stark difference between In Memoriam and the poems I wrote about earlier in this chapter. The rich and warm sunlight in the room in which the cursed sleeping beauty lies in slumber is replaced by Hallam's cold, dark home reminiscent of emptiness and loss, and Tennyson must now come face to face with depicting the reality of his strife: what words he can string together with his imagination to depict melancholy and what he must leave to be unsaid.

The images of darkness and black that these settings are made up of perfectly encompass the tone of melancholy and set the stage for the tales to come. In his article “Tennyson and the Measure of Doom," Herbert F. Tucker analyzes Tennyson's evocation of atmosphere in his works, both emotional and physical in sound and image. I would align my own argument with Tucker's insightful observation that Tennyson does tend to separate setting from sound. While Tennyson's 'scenes are more literally 'set' than those 
of most writers: vivid, immediate details stand out like jewels against a shadowy background," Tennyson eventually separates the visual and the aural, enchanting his audience with the blindness of raw emotion (Tucker, 12). When associating In Memoriam with the image and essence of melancholy, sight and sound are deeply intertwined, only to be separated in some instances:

...the hopeless speaker of the seventh lyric from 'In Memoriam'...greets the dawn with the poignant sense of discrepancy that engenders in Tennyson not irony but its cousin melancholy. Tennysonian dusk is a liminal hour, and its threshold has a clear sensory and psychic direction, away from sight into sound and feeling, away from character into passion, away from conscious will into mystic passivity. (Tucker, 12)

Canto VII explores this as Tennyson depicts himself before the empty home of Hallam after his death, which he describes as a "Dark house.../ Here in the long unlovely street.../ So quickly, waiting for a hand/ A hand that can be clasp'd no more-/ Behold me, for I cannot sleep,/ And like a guilty thing I creep/ At earliest morning to the door" (VII. 1-8). This is one of Tennyson's first representations of location in this elegy and it presents an interesting twist on the representation of place in his earlier works; while the subjects in "Sleeping Beauty," "Mariana," and "The Lady of Shalott," are confined inside, the subject of In Memoriam is hopelessly trapped outside, unable to enter the home which he desires most. The Lady of Shalott does indeed leave the tower, but it 
costs her her life; the process of her death begins at the precise moment she makes visual contact with the outside world. In addition, I hold with the notion that the seventh canto in this elegy relies heavily on blind emotion, first narrating the subject outside of Hallam's home only to discover he is not there and that "The noise of life begins again,/ And ghastly thro' the drizzling rain/ On the bald street breaks the blank day (VII. 10-12). There is a clear transition from the sight of Hallam's home to the sound of the "drizzling rain" and "the noise of life" (VII. 10-11). As Tennyson writes of sound and image, Tucker notes, “The most memorable and characteristic moments in Tennyson's poetry occur as sight is swallowed up in darkness and the visual is overwhelmed by an ascending power of sound..." (Tucker, 12). The idea of sound devouring sight holds true in canto XI, where the first half is dedicated to the poet meditating on loss ("One writes that 'Other friends remain,'/ That 'Loss in common to the race'/... That loss is common would not make/ My own less bitter, rather more"); however, the second half, while still dedicated to the theme of loss, begins to paint a picture of another allegory, a maiden waiting for her lover to come home, who may be lost at sea or fallen off a horse, destined now to be a maiden for the rest of her life ("her future Lord/ Was drown'd in passing thro' the ford/ Or kill'd in falling from his horse") (VI 1-6; 38-40). Another notable aspect of these lines is Tennyson's shift from the first person to the narrator then back to the first person, making a clear connection between the loss of the maiden to his own loss: "O what to her shall be the end?/ And what to me remains of good?/ To her, 
perpetual maidenhood, / And unto me no second friend" (VI. 41-44). In Memoriam is a poem in which Tennyson applies the technique of merging and separating sound and image. We as readers are submerged in grief; it is dark and we've lost sight of where we are and what we see. His other poems are not like this. In "Mariana" and "The Lady of Shalott," sight and sound work together seamlessly. We can hear the wind swirl and see the deteriorated state of the house in which Mariana is trapped. We can perfectly envision the tower and its four stone walls in which the Lady of Shalott is confined and hear the bustle of the outskirts of Camelot, yet darkness and mass confusion dominate the beginning of In Memoriam when the speaker begins to take in and understand his loss.

In Memoriam, in particular, with its many images, sounds, allegories, allusions, diction, and themes, gives the reader a window into Tennyson himself, who seems to display symptoms of a melancholiac in association with the color black. The speaker in In Memoriam states, "My will is bondsman to the dark" and "Dark house, by which once more I stand," immediately alerting the reader that he is unwillingly drawn to darkness and that it has become the dominant part of him (the word bondsman connotes that he is a slave to "the dark," though not voluntarily) (1-18; IV. 2-VII. 1). Furthermore, Tennyson is also able to brilliantly depict his loss in canto $\mathrm{V}$ which lacks landscape, when he writes, "I sometimes hold it half a sin/ To put in words the grief I feel" (V. 1-2). Here, Tennyson acknowledges the feeling of emptiness that comes with a heavy loss. Similarly, his lines in canto $\mathrm{V}$ "But, for the unquiet heart and brain,/ A use in measured language lies; / The 
sad mechanic exercise,/ Like dull narcotics, numbing pain" immediately bring the reader back to the here and now, thinking of the inner-workings of the mind after a painful loss (V.5-8). There are no allegories or beautifully sad images to illustrate Tennyson's grief in these lines. They express the harsh reality of loss, the idea of sadness clawing at one's heart and brain to be heard, and Tennyson's ability to numb his pain as with "dull narcotics" by manifesting his grief into his writing. Following this stanza, Tennyson is also able to depict himself through the allegory of a widow (yet another isolated, lovesick woman) when he writes, “In words, like weeds, I'll wrap me o'er,/ Like coarsest clothes against the cold;/ But that large grief which these enfold/ Is given in outline and no more" (V.9-12). The alliteration Tennyson employs with "words," "weeds," "wrap," and "coarsest," "clothes," and "cold" emphasize the allegory of Tennyson as a widow, struggling with the repetitive feeling of loss and grief. Not only do these three lines create another tender, powerful image of melancholy, they also function as a direct response to the two stanzas before it by stating that though it might be futile, Tennyson will still write and use words to numb the loss that he feels, though it might only serve as an outline and not express the full extent of his grief.

Toward the beginning of In Memoriam, Tennyson immediately makes clear that at times, he is both the narrator and the subject. In certain cantos, he does not veil his grief with allegories or other literary devices; he writes as himself and of his own experiences. Common symptoms of those who suffer from melancholy are sleeplessness, 
despondency, and a longing for death, all of which are accurately portrayed toward the beginning of In Memoriam. ${ }^{12}$ Canto VII illustrates a clinically accurate picture of someone who struggles with melancholy as well as the color associated with it. "Behold me for I cannot sleep/ And like a guilty thing I creep/ At earliest morning to the door, "' Tennyson writes, imagining himself as he stands outside of Hallam's dark home (VII. 68). In his article "The Two Kingdoms of 'In Memoriam," John D. Rosenburg bridges the gap between loss, the melancholic state, and its symptoms. "In making this pained visitation," Rosenburg asserts, "the poet has become a nocturnal creature," and the darkness of the night and the darkness that shrouds him after Hallam's death are "severing him from the waking world" (Rosenburg, 230). Tennyson alludes to this once more in the line "To Sleep I give my powers away" earlier in the elegy (IV. 1). He has lost hope, cannot sleep, and at times, longs for death; one such example is when he writes, "This year I slept and woke with pain./ I almost wish'd no more to wake" (XXVIII, 13-14). In her essay “Calculating Loss in Tennyson's 'In Memoriam,'” Irena

\footnotetext{
${ }^{12}$ Yeoman, Thomas Harrison. The People's Medical Journal, and Family Physician, Vol. L. London: George Vickers, Strand, 1850. Yeoman classifies melancholy into four separate types, three of which Tennyson expresses: "1st. Gloomy melancholy; in which the patient is silent, sad, and constantly endeavouring to seclude himself from observation. 2nd. Restless melancholy; in which the patient is roving, restless, and evinces a constant desire to change his abode. 3rd. Mischievous melancholy; marked by sullenness, moroseness, spite, and occasionally terminating in suicide or the injury of others"
} 
Hsiao claims "The division of the self is apparent from the first stanza, whose subject surrenders his will to sleep and only then begins an internal dialogue with his heart, addressing it as a localized region of loss" (Hsiao, 177). This "localized region of loss" Hsiao speaks of is indeed Tennyson's heart, which he describes at times as wrathful, "too far diseased," and “forsaken” (VIII.18-LXVI. 1). However, I depart with Hsiao's argument in that Tennyson's mind is at times this "localized region" instead of the heart as he struggles to overcome the doubt he wrestles with and put his grief into words that would do Hallam the poetic justice Tennyson thinks he deserves. One of Tennyson's major achievements in his poetry is the ability to create imaginative landscapes that directly reflect the state of the human conscience. While we see this in "Mariana," where she is imprisoned in her mind as well as the grange, Tennyson points to this is in canto $\mathrm{XCV}$ of In Memoriam. However, he does something different. Mariana is hopelessly stuck in her mental and physical entrapment while the speaker in this canto goes into a dream-like state only to come out of it abruptly and be thrust back into the darkness of his grief. The speaker finds himself with company on the lawn at Somersby, only to find himself alone all of a sudden. He experiences the company of Arthur and for a moment bliss in this dream-like state; yet after "the dead man touch'd [him] from the past," his “trance/ Was cancell'd, stricken thro' with doubt." ${ }^{13}$ (XCV, 34, 43-44). "In a mystical

${ }^{13}$ We can safely assume the speaker is Tennyson in this section, due to his and Hallam's connections with Somersby. 
trance the poet has the epiphany that transforms and transcends all the problems of the poem," Langbaum notes. And then once more Tennyson returns to his inability to put into words how he feels, such as the words he struggles to put together in canto VII: "Vague words! but ah, how hard to frame/ In matter-moulded forms of speech,/ Or ev'n for intellect to reach/ Thro' memory that which I became..." (XCV, 45-48). Once again, landscape fades into the background as silence (literally, now that he is alone, and figuratively, as he is now void of words to describe this experience) dominates sight once more. In addition to this dream-like experience, one notable aspect of Romantic literature is that it is so heavily intertwined with visions, apparitions, and hallucinations that they begin to blur the dividing lines between the imaginary and the real. We see this too in canto XCV. We also see this earlier on in the elegy, where Tennyson fantasizes that news of Hallam's death was false:

If one should bring me this report, That thou hadst touch'd the land to-day, And I went down unto the quay, And found thee lying in the port;

And standing, muffled round with woe, Should see thy passengers in rank Come stepping lightly down the plank, And beckoning unto those they know;

And if along with these should come The man I held as half-divine; Should strike a sudden hand in mine, And ask a thousand things of home; 
And I should tell him all my pain, And how my life had droop'd of late, And he should sorrow o'er my state And marvel what possess'd my brain;

And I perceived no touch of change, No hint of death in all his frame, But found him all in all the same, I should not feel it to be strange. (XIV 1-20)

In terms of tangible landscape, Tennyson offers us one central setting: the ocean, which heavily contributes to the atmosphere of In Memoriam, as it is by way of the water that the vessel in which Arthur Hallam's body was returned to his mother country. One such allusive example is in canto IX:

Fair ship, that from the Italian shore Sailest the placid ocean-plains With my lost Arthur's loved remains, Spread thy full wings, and waft him o'er.

So draw him home to those that mourn

In vain; a favourable speed Ruffle thy mirror'd mast, and lead Thro' prosperous floods his holy urn.

All night no ruder air perplex

Thy sliding keel, till Phosphor, bright As our pure love, thro' early light Shall glimmer on the dewy decks.

Sphere all your lights around, above; Sleep, gentle heavens, before the prow; Sleep, gentle winds, as he sleeps now... (IX 1-15) 
In the seascape, Tennyson unites sound and image rather than separating the two. We can visualize the ship carrying Hallam's remains, we can hear the gentle wind and placid sea, and we can picture the great star casting its light onto the deck. The enclosed rhyme scheme in this canto is an apt reflection of the "placid" waters in which the boat bearing Hallam's remains sails upon as it is consistent and reinforces the peaceful nature of the water in this canto. The speaker lists what he can see and hear upon the approaching of Hallam's vessel. The speaker continues into the next section, listing what he sees and hears: "I hear the noise about thy keel;/ I hear the bell struck in the night:/ I see the cabinwindow bright;/ I see the sailor at the wheel..../And, thy dark freight, a vanish'd life./ So bring him; we have idle dreams..." (X, 1-9). Though the ship is successful in returning Hallam's body safely, Tennyson questions whether it would be best for Hallam to "rest beneath the clover sod,/ That takes the sunshine and the rains,/ Or where the kneeling hamlet drains/ The chalice of the grapes of God;" rather than "if with thee the roaring wells/ Should gulf him fathom-deep in brine;/ And hands so often clasp'd in mine,/ Should toss with tangle and with shells (X, 13-20). Tennyson "habitually imagines the sea, which is less often briny or wine dark than oral in its attributes: vocal, devouring, or both" (Tucker, 12). The fact that Hallam's body would need to be returned by ship is not lost on Tennyson, as the ocean and the volatility of nature is a common theme in Romantic literature and his Romantic predecessors somewhat influenced his unique writing style; so it is apt, then, that Tennyson seems to dwell on the imagery of the sea. 
One such example is Shelley's Alastor; or, Spirit of Solitude, where the subject experiences the volatility of the sea, the waves lashing out at him like black serpents attempting to sink his vessel. These lines provide us with insight that Tennyson questions nature and worries about its instability and how the outcome will influence his healing process. The fact that darkness overwhelms In Memoriam's early cantos speaks to the crisis of personality the Romantics based some of their poetry on. Upon news of Hallam's death, Tennyson sees black, almost as if he were a child at the start of his material journey. As time passes on, we, as readers, follow Tennyson through a journey that's reflective of a crisis of personality; he loses his religious faith, he explores the world in tandem with his loss, and he comes out of it enlightened. He continuously inserts landscapes that are reflective of the phase he is struggling with. He questions God, questions nature and his relationship with it, questions and explores loss and its relationship with love ( "'Tis better to have loved and lost/ Than never to have loved at all"), and he meditates on his anguish, ultimately finding his way back to his family and faith (XXVII 15-16). In addition to the upset and balance between man and nature that we see in this elegy, once Tennyson regains his faith, he calls upon his muse at the beginning of his work in The Prologue, an opening very common for his Romantic forbears.

In short, In Memoriam is a piece that shifts away from Tennyson's earlier poetry in multiple ways. There is a clear struggle between Tennyson and God (a power known to 
be influential of nature), there is a clear shift from the landscape and the melancholic subject in fictitious poems to the reality Tennyson is faced with. Tennyson now invokes his muse, there are visions, there is darkness and an evolution that takes place from the start until the end of the elegy. In "The Lady of Shalott" and "Mariana" his audience is stuck in a place of stasis; there is no movement or resolution, and much of this should be considered when parsing out the shift in language, landscape, and aesthetic Tennyson makes upon writing his elegiac masterpiece. 


\section{CHAPTER III}

\section{A Baptism of Fire: Sounding the Depths of Religion and Faith in In Memoriam}

T.S. Eliot once stated of In Memoriam that it can "justly be called a religious poem, but for another reason than that which made it seem religious to his contemporaries. It is not religious because of the quality of its faith, but because of the quality of its doubt. Its faith is a poor thing, but its doubt is a very intense experience" (Eliot, 200-1). The authenticity of Tennyson's faith, as represented in the poem's narrative, lies within the personal struggle of doubt he was immersed in, learning through experience rather than accepting blind faith, beginning in darkness and ultimately ending in the light of God's grace. This chapter explores the abundance of biblical allusions in the Victorian poet's elegy, the noble Arthur Hallam's seraphic representation by Tennyson, and explains how each one contributes to the rhetoric of religion and aesthetic of In Memoriam as well as works to unite his readers with common ground. In this poem, the melancholy is shrouded in religious references which each contribute to the sadness the elegy exudes and speak to the turmoil Tennyson was intrenched in throughout his grieving process. The story of Lazarus in canto XXXII, for instance, serves as a cruel tease to Tennyson's faith. What did Lazarus see after death? Was there an afterlife? "There lives no record of reply/ Which telling what it is to die," Tennyson notes, as he still scrambles for a glimpse of hope that his friend's soul has transcended into heaven 
(XXXI. 5-7). Such investigations into his religion as portrayed throughout the elegy bore a newfound faith more genuine and purer than ever. However, the quality of doubt Tennyson faced is a testament to the resolution in which he finds solace after the seventeen-year writing process and therefore such explorations of the depths of religion should be thoroughly investigated. Though each canto was written at different points in Tennyson's grieving process, Tennyson's initial grappling to understand his friend's death is grounded in melancholy, but through his exploration of his faith, he finds comfort. Throughout the elegy, allusions to science in relation to faith are also prevalent. As I discussed in the previous chapter, Tennyson lived through an age witnessing first hand geological discoveries that would change the course of faith and the timeline of the earth permanently. Between such shattering revelations and the loss of his friend, it is reflective in Tennyson's writing that he certainly had to rethink aspects of what he believed in relation to a higher power and reconfigure his beliefs and poetry accordingly.

"We have but faith; we cannot know," Tennyson states in the untitled Prologue of In Memoriam. Though the beginning of the elegy is a nod to his strengthened faith, invoking the "Strong Son of God, immortal Love," Tennyson somewhat ironically wrote this testament to his faith last (21). ${ }^{14}$ Even though Tennyson's doubt envelops him for

\footnotetext{
${ }^{14}$ In his commentary of In Memoriam, Erik Gray writes, “This introductory poem, which Tennyson left untitled, is dated 1849; it was thus composed after the rest of In Memoriam was already completed" (5).
} 
seventeen years, his spiritual journey, that of faith and doubt vigorously at odds with one another, is deeply reflected throughout the elegy, making In Memoriam the most religious of English elegies and thus inviting comments from prominent literary figures such as W.H. Auden and T.S. Eliot, who, though they take issue with some aspects of the elegy, acknowledge the quality of the poem based on its religious nature. Though the Prologue is a beautiful ode to Christianity, what follows in the earlier cantos is reflective of the sudden pain and shock Tennyson feels upon losing Hallam, and allusions to and images of the Bible are immediately present for Tennyson's readers as he begins his elegy. Such allusions are abundant throughout the poem and lend a unifying hand to Tennyson and his readers while also expressing how piercing the loss of Hallam was to Tennyson. Before Tennyson turns to religion alone, he acknowledges Death, who "graspest at the stones/ That name the under-lying dead" and Sorrow "Priestess in the vaults of Death" (I, 1-2, II, 2). Following these sections are more stanzas that feel closer to Hallam's death than the later ones. Not only does Tennyson feel the raw pain of losing his friend in the beginning cantos, he is also particularly drawn to the notion of resurrection. Canto VII explores this as Tennyson depicts the image of himself at the empty home of Hallam after his death, which he describes as a "Dark house...Here in the long unlovely street.../ So quickly, waiting for a hand/ A hand that can be clasp'd no more-/ Behold me, for I cannot sleep,/ And like a guilty thing I creep/ At earliest morning to the door./ He is not here; but far away..." (VII. 1-9). This is one of the first instances in which Tennyson 
depicts his lost friend as a Christ-figure, where he writes, "He is not here; but far away," an allusion to the gospels where the people gathered around the sepulcher of Christ only to hear from the angel guarding it that "he is not here" (VII. 9; Matthew 28:6). ${ }^{15}$ These stanzas acknowledge that Tennyson is experiencing a state of denial over Hallam's death. He revisits the home of Hallam after his death and writes, "He is not here," as if he thought there was but a chance that he might be. In John D. Rosenberg's article "The Two Kingdoms of In Memoriam,” Rosenberg makes the insightful comment that Tennyson's initial shock of Hallam's death “is heightened by a probable allusion to the Gospels...St. John, the angel announces before the empty sepulcher, 'He [Jesus Christ] is not here' but has risen in immortal glory" and Tennyson stands before Hallam's dark and empty home, now an image of Christ's tomb (Rosenberg, 230-231). Once again, Tennyson is able to transcend his own grief and insightfully compare his dear friend's death to one similar to Christ's, giving meaning to Hallam's death and the sadness that followed. Not only are neither Christ nor Hallam "there," it seems God is absent too, for even though Tennyson expresses religious doubt, it is still shrouded in biblical allusions which he is able to alter for his own pessimistic purposes. Furthermore, the biblical

15 The New King James Bible. Thomas Nelson Publishers, Nashville: Thomas Nelson Inc. 1982. 
allusion would have been understood and felt by well-versed Victorians; again, Tennyson is able to unite his readers. Tennyson furthers the emptiness he feels when he writes "And learns her gone and far from home," yet another allegory of a lover losing a loved one. And then "So find I every pleasant spot/ In which we two were wont to meet,/ The field, the chamber, and the street,/ For all is dark where thou art not" (VIII. 9-12). Here, Tennyson is still grasping at any chance he can get to feel Hallam's presence again. Though Tennyson was able to glorify Hallam's death in a way, the "tomb" is still empty and Tennyson is once again left with the grief one feels after losing a loved one.

By interlacing Tennyson's faith with Hallam's death, "Hallam himself [becomes] a citizen of both realms, of the heavenly city which is to be manifested on earth and of the earthly city which is to evolve into the divine" (Rosenburg, 236). Throughout the elegy, it is explicit that Tennyson is exploring his own faith (or lack thereof) to account for his loss and whether Hallam's soul has become immortal in the kingdom of God. However, though doubtful at some points, in many instances, Tennyson acknowledges God's role in Hallam's death, suggesting that Tennyson perhaps always believed in God but doubted his omnipresence and care for his earthly creations. Beginning with his departed friend's death, Tennyson writes, “That in Vienna's fatal walls/ God's finger touch'd him, and he slept (LXXXV. 19-20). In this instance, Tennyson chose to portray Hallam's death as being touched by God's finger when there would have been an abundance of ways to convey how Hallam died. Though the diction is gentle, it seems as 
though God is responsible for Hallam's death in a way. Does Tennyson blame God for Hallam's death? In addition, cantos XXXI and XXXIV offer a particularly interesting window into Tennyson's mind as an instance of questioning his faith. In his retelling of the story of Lazarus, a man who was resurrected from the dead by Jesus (as told in the Gospel of John 11:1-44), Tennyson seems to be fixated on the fact that the people never got an answer as to where Lazarus was the four days he was dead (again, "Where wert thou, brother, those four days?'/ There lives no record of reply,/ Which telling what it is to die") (XXXI. 5-7). Later in the elegy, Tennyson makes another allusion to the story of Lazarus: “[Mary Magdalene's] eyes are homes of silent prayer,/ Nor other thought her mind admits/ But, he was dead, and there he sits,/ And he that brought him back is there" (XXXII, 1-4). ${ }^{16}$ Tennyson is preoccupied with the possibility of an afterlife, and dwells upon this particular story of the man Jesus resurrected. This allusion to the Bible, and particularly resurrection, speaks to Tennyson's own grasping at any chance to confirm that there is salvation in God's grace; his focus on where Lazarus was after he died seems like a cry for help and a major line of thinking that writes itself out throughout the elegy manifesting itself through confusion and hope. The resurrection of Lazarus was initially for the disciples of Christ in order to convince believers and nonbelievers alike of the power of Christ and to encourage them to put their faith in him. In John 11:25, Jesus

\footnotetext{
16 Tennyson aligns himself with Mary, the sister of Lazarus, which I will discuss in the next chapter.
} 
Christ comforts Martha and Mary, the sisters of Lazarus, who had already been dead for four days with the promise that he will rise again: "I am the resurrection and the life. He who believes in me will live, even though he dies; and whoever lives and believes in me will never die." ${ }^{17}$ Although the resurrection of Lazarus represents a literal manifestation of the promise of Christ, the passage should be more literally interpreted as the souls of the pious who follow Christ will transcend into an afterlife upon their earthly death. Tennyson, who clearly understands that Hallam will not literally be raised from the dead like Lazarus (though, he does in some sense wish it could be possible: "He is not here; but far away...”), finds solace in the hope that Hallam's soul achieved life after death. In his book Faith and Doubt in the Century's Poets, Richard A. Armstrong reflects on Tennyson's relationship with Hallam, writing that for "four years that pregnant friendship endured, strengthening with every month, and then came the tidings that in the distant Vienna, Arthur Hallam...had closed his eyes in death" (Armstrong, 71). Hallam's death was the turning point for Tennyson, and In Memoriam "brings out with impressive clearness how that immense bereavement wrought on the poet's soul. It was to him the baptism of fire. For seventeen years his sprit dwelt upon the sorrow, the

17 The New King James Bible. Thomas Nelson Publishers, Nashville: Thomas Nelson Inc. 1982. 
mystery, the seeming broken promise of that brilliant life cut" (Armstrong, 71-72). This baptism of fire represents the internal struggle Tennyson seems to endure over this period of self-reflection, a period of faith and doubt where the poet explores his faith and haunting skepticism that "sounded the depths" (Armstrong, 76). However, as Armstrong notes, "men may meet these vast and haunting doubts in any of three separate fashions," and while Tennyson could have fled from the doubt in affright only to "cling still to the ancient creed" or yield to the doubt and "fling away the faith," Tennyson chose to confront the doubt, play with it, explore it, and measure it (Armstrong, 76-77). Tennyson speaks of this courage when he writes that "he" (presumably Tennyson) has, "The faith, the vigour, bold to dwell/ On doubts that drive the coward back" (XCIV, 29-30). This assertion demonstrates Tennyson's self-awareness and in this way, Tennyson is able to transcend his grief and his doubt in the purest form: by facing it head on.

Tennyson clearly displays a rapid struggle between atheistic despair and confidence in his Christian faith throughout the narrative, which is his stream of consciousness and is reflective of a diary, as T.S. Eliot once declared: "In Memoriam is the whole poem... a long poem made by putting together lyrics, which have only the unity and continuity of a diary...a diary of which we have to read every word" (Eliot, 196). ${ }^{18}$ T.S. Eliot's positive commentary on the unity of the poem is one of many, yet several

18 Eliot, T. S., Essays Ancient and Modern. Harcourt Brace and Company, 1936. Print. 
other critics disagreed, writing that In Memoriam was hastily weaved together. ${ }^{19}$ In his article "In Memoriam: Twentieth-Century Criticism," Joseph Sendry replies to Eliot's comment with "But a diary has a low degree of order, and a mandate to read every word is no guide to analysis" (Sendry, 106). Though I disagree with Sendry's almost insulting comment, I feel it is a testament to just how divided scholars are on the issue of unity, and that diaries are highly personal and raw, an aspect of In Memoriam that, I feel, validates the emotional journey Tennyson publicized. The sometimes confusing structure of the elegy speaks to its speaker's emotional vacillation. Make no mistake, Tennyson is aware of this clash between "calm despair and wild unrest" (XVI, 2). Though, as the elegy progresses towards hope and final acceptance, the depth of his doubt is clearly expressed in cantos such as LV and LVI, where Tennyson broods:

The wish, that of the living whole No life may fall beyond the grave Derives it not from what we have The likest God within the soul?

Are God and Nature then at strife, That Nature lends such evil dreams?

${ }^{19}$ Sendry draws upon multiple critiques of In Memoriam. Paul F. Baum, whom Sendry cites, posed questions of unity, which Sendry describes as “questions [Tennyson's] predecessors had skirted and gave emphatically negative answers. The poem, as [Baum] saw it, was hastily and arbitrarily assembled from materials that are incompatible in genre (the personal elegy and the philosophical poem) and style...'Parts of the poem will live,' he predicted, "but as a single poem it has had its day and ceased to be"' (Sendry, 106). 
So careful of the type she seems,

So careless of the single life;

That I, considering everywhere Her secret meaning in her deeds, And finding that of fifty seeds She often brings but one to bear,

I falter where I firmly trod, And falling with my weight of cares Upon the great world's altar-stairs That slope thro' darkness up to God,

I stretch lame hands of faith, and grope, And gather dust and chaff, and call

To what I feel is Lord of all, And faintly trust the larger hope. (LV, 1-20)

Tennyson's reflective nature in his elegy provides an emotional account of his grief over the death of Hallam and his strife in finding solace in his wavering religious conviction, while also questioning larger existential issues, such as the struggle I mentioned in the previous chapters between God and nature (which are reminiscent of Tennyson's Romantic forbears), grief and comfort, faith and doubt. Tennyson struggles to believe in the "larger hope."

Tennyson also acknowledges the tense relationship between God and nature, due to the scientific discoveries of his age. The alliteration of the words "falter," firmly," and “faintly" express exhaustion and desperation on Tennyson's behalf. Though the meter is consistent with the exception of "lame hands" (a spondee), the alliteration emphasizes these stanzas and suggest that Tennyson feels he's been defeated by death, though he 
refuses to give up the "larger hope," presumably God's master plan that only the divine are privy to and those on earth are merely left to trust. By writing, "Who trusted God was love indeed / And love Creation's final law_ / Tho' Nature, red in tooth and claw / With ravine, shriek'd against his creed," Tennyson seems to question the merciless and cruel facets of God (LVI 13-16). Nature is a hostile, shrieking Fury "red in tooth and claw," who cries "I bring to life, I bring to death," usurping the role of the Prologue's Strong Son of God who "madest Life" and "madest Death" (LVI, 6; II, 6-7). Why are his creations cruel in so many ways? There is death and destruction everywhere, for postlapsarian nature is full of violence and blood. The lion who stalks its prey does not offer niceties when it rips into the flesh of the animal it has hunted. This deep-rooted unbalance between God and nature Tennyson sees in the world is the catalyst for much of his doubt. This makes sense when considering how young Hallam was when he died unexpectedly at only twenty-two. If a good and compassionate God existed, how could he allow Tennyson's beloved friend to perish so young? In his book Writers and Their Background, John Jump asserts, Tennyson's “experiences naturally lead him to questions about death and survival after death and the existence of a loving God" (Jump 99). Though "We have but faith; we cannot know," Tennyson also finds error in much of the physical world ("I found Him not in world or sun,/ Or eagle's wing, or insect's eye"), proving it hard for him to collect direct evidence of God's existence (CXXV, 5-6). Jump further comments, "Tennyson, however, was something of a Coleridgian and a good deal 
of a modern in that he based his belief in God not upon external evidences but upon inner experience" (Jump 106). Tennyson's initial reaction to Hallam's death as well as when he comes out of his sorrow is consistent in that he constantly notes in his elegy that it is hard for him to find God in material things or in nature. The heart is where his spiritual journey must take place.

In his article “Tennyson's Honest Doubts,” Basil Willey uses several passages from In Memoriam to convey that Tennyson loses his Christian faith in part due to the laws of nature. Willey claims that Tennyson sees how insignificant we are in the grand scheme of things, for there is a vastness and complexity in this universe that we may never understand. In canto LIV, Tennyson attempts to reconcile the loss of his friend with the hope that something good can come from death, whether it be through the solace of an eternal life in heaven or simply a sense of closure: "Oh yet we trust that somehow good/ Will be the final goal of ill,/ To pangs of nature, sins of will,/ Defects of doubt, and taints of blood;" (LIV; 1-4). He refers to doubt as a defect, pairing it with a trochee rather than an iamb, creating an actual defect in his usually flawless iambic tetrameter. Tennyson also seems to be alluding to the black blood of the Tennysons with the words "taints of blood;" perhaps he is recognizing the fact that though his family line is prone to mental illness, he somehow must trust that God has a reason for these "defects." However, Tennyson moves on and speculates whether or not life is aimless, due to the intensity of grief in which Tennyson finds himself without God's consolation or religious 
intervention. Once more, Tennyson turns to doubt and defeat making the statement "Behold, we know not anything;/ I can but trust that good shall fall.../ So runs my dream: but what am I?/ An infant crying in the night:/ An infant crying for the light:/ And with no language but a cry" (LV; 13-20). Here, the speaker laments that humans can never truly know anything; we are but infants with no way to express ourselves other than crying helplessly and aimlessly.

As I discussed earlier, the Victorian crisis of faith is common as well as present in this text, therefore looking at Biblical references that address such doubts side by side with In Memoriam can lend a helping hand in attempting to think as Tennyson did when writing his elegy. Tennyson himself wrote, "Perplext in faith, but pure in deeds.../There lives more faith in honest doubt" (XCVII; 9-10). When we compare such "honest doubts" to Biblical stories, these doubts Tennyson faces head on are not as uncommon as one might expect. King David in the Book of Samuel, for instance, expresses his hopelessness sometimes, doubting God and feeling abandoned. He once lamented "My God, My God, why have You forsaken Me? Why are You so far from helping Me?" (Ps. 22:1). However, King David defeated his doubt and came out of his spiritual awakening much like Tennyson does. Similarly, in the New Testament, the apostle Paul, arguably one of the most faithful servants of God, had his own struggles with doubt as well: "O wretched man that I am! Who will deliver me from this body of death?” (Rom. 7: 24). Jesus, too, vocalizes his feeling that God has forsaken him in the Garden of Gethsemane, 
asking God to provide an alternative route to salvation (without being beaten and crucified), despite the fact that he is the human manifestation of God (Matt. 26: 36-39; Matt. 27: 46). ${ }^{20}$ All of these biblical figures experience the human emotion of religious doubt, yet overcome it. Jump continues in his assertion, "But In Memoriam, in its hope and its despondency, its doubt and its faith, possesses an inwardness and a desperate sincerity, recorded with the most delicate artistry, that make it unquestionable its author's major achievement as a religious poet" (Jump 114). Though Tennyson's experience with doubt and despondency are unmistakably apparent throughout the poem, faith and hope triumph in the end. When looking at Tennyson's elegy as a whole rather than individual cantos, it is clear that Tennyson looked at the evidence, pondered it intensely, expressed honestly his conflicting emotions and the spiritual battle he was fighting, and came to his conclusion, which is the most clearly expressed in The Prologue. However, each biblical allusion Tennyson writes initially contributes to the immense doubt he felt, and while he uses the Bible to express his doubt, in the end, he most commonly uses it to express his newfound faith.

20 The New King James Bible. Thomas Nelson Publishers, Nashville: Thomas Nelson Inc. 1982. 


\section{CHAPTER IV}

\section{Tennyson's Final Admission (The Prologue)}

The Prologue of In Memoriam, the portion of the elegy that was written last, within which our poet declares his newfound hope and faith in God, serves as Tennyson's final testimony to the religious strife he endured for seventeen years after Hallam's death and the resolution he sought and obtained. At last, Tennyson finally realizes his beloved friend Arthur Hallam has transcended into heaven, his soul eternally enshrined in the Lord's arms. The Prologue provides another facet of my argument, as it proves that after Tennyson's seventeen-year spiritual journey, he willingly comes around full circle to embrace his Christian faith once more. In this chapter, I reference religious allusions Tennyson makes in relation to his newfound faith, specifically how Tennyson aligns himself with the disciples of Christ and other biblical figures as well as relates Hallam to Christ and how this connection might have brought the poet comfort. In addition, Tennyson explores forgiveness, not just from God and Christ, but from himself. As the elegy progresses, we slowly see Tennyson insert moments in his elegy in which he expresses that it is acceptable to have such doubts and it is meaningful to shape your own, personalized religion, a mixture of the formal doctrine he was taught combined with his newfound understanding of his faith. All of these facets contribute to the overall tone and the aesthetic of In Memoriam. Though darkness dominates the initial sections of the elegy, there are joyful moments the speaker shares with the audience, such as The 
Prologue, where he praises Christ while also inferring to the audience that there is still work for us to do as a collective whole, leaving us with a hint of Tennysonian melancholy. Though the Prologue was written last yet placed first, this fact sets the audience up to know what is coming later in the elegy. Tennyson begins by invoking his muse, a common theme in pre- $19^{\text {th }}$-century literature, then asks for forgiveness for ever doubting his muse (Jesus Christ). As readers, we now know what to expect. Tennyson commented on this aspect as well: "[In Memoriam] begins with a funeral and ends with a marriage - begins with death and ends in promise of a new life - a sort of Divine Comedy, cheerful at the close." 21 The Epilogue is an epithalamion which honors the marriage of Tennyson's sister, while the Prologue also begins on a positive note, which is reflective of where Tennyson was after completing his seventeen year spiritual journey. The death he speaks of only reveals itself after we have read the positive aura The Prologue so effectively and elegantly emanates. It is fitting that the melancholic nature of the elegy's narrative is framed with a powerful beginning and close because this positivity speaks to the resolution that Tennyson's earlier works needed, and readers can finally feel a sense of unity in the elegy, whereas the endings of "Mariana" and "The

${ }^{21}$ James Knowles, 'Remarks of Tennyson' in 'A Personal Reminiscence', The Nineteenth Century, XXXIII (January, 1893). 
Lady of Shalott" feel fragmented. This shift from tragedy to resolution is one of the greatest markers of Tennyson's aesthetic shift.

Tennyson's seeming fixation on Hallam as a Christ figure is an exceedingly significant connection that Tennyson makes. At first, Tennyson is in a fog about Hallam's death, but slowly, he begins to connect the dots that perhaps not all is lost and he can relate to those who grieved Christ as he is grieving Arthur Hallam. One such example is in canto CXXIX, where Tennyson refers to Hallam as "Known and unknown, human, divine" (1.5). Hallam is now both human and divine, mortal and immortal, much like Christ. However, with this realization comes doubt. Just as some in the Bible, such as St. Thomas, questioned Christ's resurrection, Tennyson has no assurance that Hallam's soul lives. How can anyone be sure there is life after death? Tennyson realizes, "We have but faith: we cannot know, /For knowledge is of things we see" (1.21-2). This doubt is precisely what Tennyson grapples with throughout In Memoriam. However, just as the apostles followed and had faith in Christ, Tennyson,

Perplext in faith, but pure in deeds, At last he beat his music out. There lives more faith in honest doubt, Believe me, than in half the creeds. He fought his doubts and gather'd strength, He would not make his judgment blind, He faced the spectres of the mind And laid them: thus he came at length To find a stronger faith his own. (XCVII, 9-17) 
Tennyson sounded the depths of his religious skepticism; is there a God or hope of eternal life? Tennyson did not run from the challenge nor "yield to the assault of doubt and fling away faith;" rather, he endured the scorching inferno that baptized him and came out of it with a purified faith in spite of the haunting questions he dared to face (Armstrong, 76).

Shifting to Tennyson's final embrace of Christ's salvation, in his article “Tennyson's 'In Memoriam,"” Jeffrey Howard focuses on the elegy's Prologue and Tennyson's invoking of the "Strong Son of God, immortal Love," writing "the nature of eternal love as the predominant divine attribute that Tennyson associates with Jesus Christ, in whose redeeming and resurrecting power he has faith concerning the eventual salvation of himself and his friend" (Howard, 231). Tennyson writes that we can only embrace Christ by "faith, and faith alone," acknowledging that the resurrecting power of Christ is the only way he will be reunited with Hallam one day (I. 3). Tennyson knows that if there is a way, the only way he and his friend will be reunited one day will be through the resurrecting power of Christ. In the words "immortal love", Tennyson expresses that Christ is "the embodiment of pure love, and because of his love, resurrection will occur" (Howard, 233). Another notable aspect of In Memoriam's Prologue is when Tennyson illustrates his faith when he writes, "Thou wilt not leave us in the dust," expressing his conviction that one does not die after mortal death, but rather that through Christ, life is the end of death in that the immortality of one's soul lives on 
after its physical passing (I. 9). In addition, Tennyson's prayer for forgiveness in the Prologue ("Forgive my grief for one removed,/ Thy creature, whom I found so fair./ I trust he lives in thee, and there/ I find him worthier to be loved") and his recognition of immortal Love (i.e., Christ)...through whose love men will be resurrected-illustrates his decision to trust in Christ for the salvation of his [and Hallam's] soul" (Howard, 233). Not only does Tennyson ask for forgiveness, he also seems to desire renouncing his present state of doubt and give up his will to live in God's grace and "commence a new life in Christ" (Howard, 233).

After the invocation of Jesus Christ, his muse, Tennyson employs anaphora in the lines, "Thou madest Life," "Thou madest Death," "Our wills are ours," and "Our wills are ours" $(6-7,15,16)$. While in the early cantos of In Memoriam written chronologically before the Prologue Tennyson attributes these characteristics of creation and destruction to nature, Tennyson seems to be able to reconcile the close relationship between God and nature, no longer viewing nature as a hostile, destructive force, but rather intertwined with God. As I stated in the previous chapter, Tennyson's pantheism fits into this concept that God is everywhere, in everything. William Allingham, the man who documented this admission on Tennyson's part ("Well!... I think I believe in Pantheism, of a sort"), published his diary 15 years after the publication of In Memoriam and 32 years after the poem was started. This suggests that Tennyson had used the writing process to reflect on his true beliefs and develop these thoughts into 
conclusions. ${ }^{22}$ After this shift in attitude toward the relationship between God and nature, Tennyson again alludes to a connection between Hallam and Christ, who he states, "seemest human and divine," qualities he had also given to Hallam in canto CXXIX (13). "Our little systems have their day," Tennyson states before continuing, "They have their day and cease to be:/ They are but broken lights of thee,/ And thou, O Lord, art more than they" (17-20). In these lines, Tennyson seems to grasp that humanly devised systems ("humanly conceived theological, philosophical, and scientific systems") are mortal, and will perish and ultimately be replaced (Gray, 5). The Father and Christ are above such humanly devised creeds, and we, as mere mortals, can only attempt to create reflections of Christianity in our everyday lives, though we will never entirely succeed. Tennyson continues this notion in the lines "Let knowledge grow from more to more,/ But more of reverence in us dwell;/ That mind and soul, according well,/ May make one music as before (25-28). These stanzas emphasize the relationship between religion and knowledge. The scientific advancements in geology and biology that the Victorians experienced firsthand caused severe bouts of religious doubt. No longer was God omnipotent; instead, earth and those living on it changed on their own without divine intervention. ${ }^{23}$ The Victorians simply could not return to a time without these

\footnotetext{
${ }^{22}$ Allingham, William. William Allingham's Diary. Fontwell (Sx.): Centaur P., 1967. Print. Centaur Classics.

${ }^{23}$ I mention this notion in chapter II, where I reference evolutionary theory.
} 
groundbreaking discoveries but instead had to work with them and reconcile their faith with a new understanding of the earth. Lastly, Tennyson ends the Prologue with multiple counts of alliteration: "Forgive these wild and wandering cries,/ Confusions of a wasted youth;/ Forgive them where they fail in truth,/ And in thy wisdom make me wise" (I, 4144). It is clear that after much reflection and meditation, Tennyson asks God and Christ for forgiveness for his grief and subsequent doubt, reinforcing this notion several times with the alliteration of "wild," "wandering," "wasted," "where," "wisdom," and "wise." The diction in this stanza is pure and raw. Once again, words do not entirely suffice; Tennyson intentionally uses these words to create an unfiltered tone. He is (or was at first) confused, comparing himself to a child multiple times throughout the elegy. He humbles himself and asks for forgiveness rather than creating a tone that suggests his doubt was mature and polished.

Tyler Tichelaar's article, “Christ, King Arthur, and Arthur Henry Hallam in Tennyson's Idylls of the King" is an exceedingly helpful text in making correlations between Hallam and Christ. Because Tennyson wrote "Morte d'Arthur" after Hallam's death, critics such as Tichelaar have drawn similarities between Tennyson's representation of both King Arthur and Arthur Hallam as Christ figures. Much like In Memoriam, "The Passing of Arthur" is essentially about "upheaval and catastrophe" 
(Tichelaar). ${ }^{24}$ This takes shape in the reaction of the apostles as well as Bedivere's reaction to King Arthur's death. Just as St. Thomas and Bedivere expressed doubts of their respective friends' immortality, Tennyson expresses this doubt over Hallam's. Because there are no physical remains to show that Christ or Arthur ever existed, Tennyson acknowledges that he knows there is no true assurance that Hallam lived on after death. Just as Tennyson states, "We have but faith; we cannot know," he mirrors this same concept in the opening lines of the Prologue: "Strong Son of God, immortal Love,/ Whom we, that have not seen thy face,/ By faith, and faith alone, embrace,/ Believing where we cannot prove;" (1. 1-4). Blind faith is irresolute, but just as the apostles followed and believed in Christ, Tennyson will do the same. Hallam, like Christ, is also represented in In Memoriam as an all-knowing figure in the universe. Tennyson describes Hallam as "Known and unknown, human, divine," and later on writes, "thou, dear spirit, happy star,/ O'erlook'st the tumult from afar,/And smilest, knowing all is well' (CXXVIIl.18-20). Hallam is no longer a man but now immortal in God's grace, watching down on the world from afar and understanding God's plan while those on earth can only try to comprehend it. This is also reflective of Christ and the apostles, as Christ knew his crucifixion was a part of a larger plan while the apostles watched him die painfully,

${ }^{24}$ Tichelaa, Tyler. "Christ, King Arthur, and Arthur Henry Hallam in Tennyson's Idylls of the King." Children of Arthur, 25 Nov. 2013. 
unable to understand his death to its full extent. Another similarity between In Memoriam and "The Passing of Arthur," Tichelaar notes, is that King Arthur is carried off on a barge after his death and so it is fitting that Arthur Hallam died overseas and thus, had to be transported back to England to be buried. The canto in which Tennyson describes the vessel carrying Hallam's body is notable, as it is one of the few times he directly refers to his lost friend by his first name, Arthur, immediately alluding to King Arthur and thus, Christ, as Tennyson seems to hold all three of these figures in close regard to one another. As In Memoriam comes to a close, it is clear that Tennyson believes his departed friend lives on through Christ. In Matthew 28:20, when the eleven disciples meet a resurrected Christ in Galilee, Christ tells his disciples, "And know that I am with you always, until the end of the world!" 25 Tennyson expresses a similar notion in canto CXXX: "Thy voice is on the rolling air;/ I hear thee where the waters run;/ Thou standest in the rising sun,/ And in the setting thou art fair..../ Far off thou art, but ever nigh;/ I have thee still, and I rejoice;" (1. 1-4, 13-14). Just as the disciples of Christ followed him until and after his death, publicly worshipping him and spreading the word of salvation, Tennyson is announcing his friend's newfound immortality in his elegy, which is made

25 The New King James Bible. Thomas Nelson Publishers, Nashville: Thomas Nelson Inc. 1982. 
public and distributed. One particularly rich allusion to the Bible is in canto XXXII, where Tennyson references Mary Magdalene and her love for Christ: "All subtle thought, all curious fears, / Borne down by gladness so complete, / She bows, she bathes the Saviour's feet / With costly spikenard and with tears" (XXXII, 9-12). When Christ raises Lazarus from the dead, Mary Magdalene expresses her love and gratitude by washing the feet of Christ with an expensive perfume and using her own hair to wipe his feet. The significance of these lines lies in the humility of Mary's action. At this point in the elegy, Tennyson refers to the remembrance in the Gospels of Mary's love for her Lord. Perhaps this speaks to Tennyson's own long-awaited epiphany that he, too, loves God and Christ, forgives them for taking the life of his beloved friend, and humbles himself by identifying with Mary Magdalene who relinquishes her pride to express her great love for Christ. Following this significant canto and with faith and doubt still in mind, Tennyson writes:

Thou that after toil and storm Mayst seem to have reach'd a purer air, Whose faith has centre everywhere, Nor cares to fix itself to form,

Leave thou thy sister when she prays, Her early Heaven, her happy views; Nor thou with shadow'd hint confuse A life that leads melodious days.

Her faith thro' form is pure as thine, Her hands are quicker unto good: Oh, sacred be the flesh and blood 
To which she links a truth divine!

See thou, that countess reason ripe

In holding by the law within,

Thou fail not in a world of sin, And ev'n for want of such a type. (XXXIV, 1-16)

In Erik Gray's edition of In Memoriam, his footnote for this canto reads,

Tennyson imagines a brother and sister of his own day. The brother ("thou") has been through 'toil and storm' of doubt and developed his own faith, unattached to form, i.e. any particular religious denomination. The sister retains to the more formal doctrines she learned in childhood ("her early Heaven"). The speaker warns the brother that such faith is just as "pure" and true as his own and should not be needlessly disturbed. (Gray, 27)

In addition to this beautiful interpretation, Gray notes, “'In holding by the law within' can be translated into those who 'consider it more rational to develop one's own understanding of faith"” (Gray, 27). This is a particularly apt wording, as Tennyson needs to reconstruct his own understanding of his Christian faith, which is not only a part of a formal doctrine, but his own personal faith shaped by his grief as well as the social and political issues in relation to faith that were greatly debated during the time he wrote this highly personal elegy. Tennyson then must lyrically engage with his readers and write a representation of what his newfound faith is. While the Prologue and the elegy leans 
toward a Christian faith or Christian ideals, there are other places, such as the above canto, where he inserts a different understanding of what faith can mean to an individual.

Though the elegy begins and ends on a happy note, beginning in a declaration of faith and ending in the marital union of two people, the melancholic aesthetic still adheres in Tennyson's reconfiguration of style, including the poem's religious aspects. Even though Tennyson believes in Christ and salvation, he acknowledges that blind faith is all we have, and that he was lost like a child but newly found. Though he continuously juxtaposes lightness and darkness together, it serves its purpose best in the Prologue, where we can see where he was and where he is now. The speaker praises God in that the moon and the his "orbs of light and shade," states that our daily lives "are but broken lights of thee," and implores God to "help thy vain worlds to bear thy light" $(5,19,32)$. He also refers to God's grace as "A beam in darkness" and to "let it grow," leaving the audience with hope while also inferring that we have not reached our full potential yet, and that we must allow ourselves to be open to accepting the power of Christ (24). Again, Tennyson seems to relinquish the romantic melancholy he draws upon in his other poems, and allow darkness to still overshadow the light he has found in his spiritual journey, leaving an ominous tone. There is still much uncertainty, for even though the speaker has regained hope and happiness, he urges his readers to do the same. Darkness and death will always linger in this world, but through Christ, from the ashes of a fire new, immortal life can grow. 


\section{Conclusion}

In Memoriam is a poem that tests the realms of religion in relation to doubt, provokes questions about the relationship between grief and unity, represents nature as cruel, and explores the bounds of melancholic manifestation and imagery in poetry. The Victorian crisis of faith and the Romantic crisis of personality work seamlessly together in Tennyson's elegy to portray his grief in the sense that he has lost not only his dearest friend, but his religious faith and sense of self as well. Tennyson tackles such an existential threat through his elegy in the most powerful way, grieving, reflecting, and chronicling his grief. His readers can witness the baptism of fire that consumed his spirit and body for almost two decades, before emerging pure and with a stronger faith than before. Because Tennyson's work draws upon that of the Romantics, throughout In Memoriam we can track the many instances of an ode to Tennyson's forbears. The symbol of the ocean, for instance, is significant, as it both symbolizes God and the volatility of nature. Apparitions of the mind are also present in this text as we witness the hopeless speaker of In Memoriam fantasizing with great vividness that his friend is alive and well. All of these aspects contribute to the poem's aesthetic of religion and melancholy, which Tennyson expresses with his use of biblical allusions, images of nature, and the juxtaposition of lightness and darkness (not only figurative but literal as well). 
The rhetoric and aesthetic of melancholy that Tennyson's earlier poetry most perfectly demonstrates is reconfigured upon writing his elegy. Again, the pink sunset and Lancelot's mesmerizing appearance work perfectly against the mystery and wickedness of the curse the Lady of Shalott is saddled with to juxtapose lightness and darkness. The state of Mariana's mind is perfectly reflected in the broken elements of the grange she paces, and the sleeping beauty's lighter elements contrast against her black tresses of hair. The speaker of In Memoriam is also entrapped in an emotional state of distress, but is able to work through the fog and ultimately finding peace in lighter landscapes, joy in newfound faith, and closure in God's eternal grace. Ultimately, even though the passing of Arthur Hallam weighed heavily on Tennyson's soul for many years and transformed him through a painful baptism of fire, becoming angry and disillusioned with nature, his poetry, which he at first was not sure could do Hallam's death justice, helped him in his grieving process. Robert Hass, in his article "The Mutable Locus Amoenus and Consolation in Tennyson's In Memoriam," writes

Moving beyond his personal struggle with the destructive forces of nature, Tennyson ultimately believes that poetry is a useful medium that can show people how to cope with a world whose religious certainties have been shattered by nineteenth-century materialism. For Tennyson, the discovery that imaginative 
activity is a saving medium that can be shared by others is finally the best and most acceptable resolution to In Memoriam. (Hass, 686)

Reflecting back on my argument as a whole, I feel it is always important to express one's emotions, particularly those brought on by mental illness, in an artistic way. As we have seen in the intimate relationship between Tennyson and Queen Victoria, literature truly does have the power to bring people together and ultimately heal through artistic expression. I feel as though the Victorian era perfectly expresses this notion, not only because, as contemporary readers, the literature that came out of that time period was a predecessor to our own but because it is always important to have open, honest discourse about mental illness, destigmatizing it, and expressing our pain in the written word. I also feel my work is important in that it offers insight into the lives of Victorians. I feel as though there has always been a general opinion that our Victorian predecessors were stoic, private people who tabooed mental illness and talking openly about it. This, we find throughout my research, is not the case. I also think it's important to track a writer's journey and to see how their style adapts to socio-economic, political, religious, and emotional changes, as well as other stressors that may change their writing. Without literature, our historical and cultural lives would be forever changed, leaving an immense hole in the way we as a society can grow together. Tennyson, in my opinion, is one of the most well-articulated, beautiful, skilled poets to come out of the $19^{\text {th }}$ century. I have 
always been drawn to that historical era that he lived through, so studying and analyzing a variety of his poems was extremely educating and inspiring as a poet in my own right. I cannot express enough how much reading and studying In Memoriam changed my perception of poetry as a genre. I am so grateful to have had the chance to find it in myself to take on such a large work in relation to grief, melancholy, and other human emotions that unite contemporary and Victorian readers alike.

As I stated in previous chapters, Tennyson's other poetry is problematic in that there is never truly resolution to the chaotic nature of his narratives. In Memoriam is the poem in Tennyson's oeuvre that finally offers resolution to both the speaker and the readers. Throughout the elegy, Tennyson upholds his great skill of writing melancholically through multiple tropes such as syntax, imagery, diction, and meter, as well as transitions from melancholy and doubt to faith and intertwining the three. Tennyson contends with the many phases of grief, using sound and image to portray the extent of his loss and submerge his readers into the depths of grief as well. Tennyson's magnum opus expresses this tone while also taking its readership on the same journey Tennyson was on, its cantos encrusted into the formation of the elegy like gems on a diadem, the Prologue embellished at the center. In the end, perhaps Tennyson's final grasp of his faith is concluded, ironically, in the Prologue, which he wrote many years after the weaved together elegy itself. I agree with Rosenburg in his assertion that "This 
final admission is extraordinary, for it climaxes seventeen years of obsessive meditation on the death and after-life of [Tennyson's] friend. It epitomizes the energetic conflict between doubt and the will to believe..." (Rosenburg, 229). Though Tennyson's melancholy goes through many stages throughout the elegy, it becomes clear that his faith is what bridges the gap between Hallam's death and the acceptance of it. The elegy itself is Tennyson's final admission that the death of a loved one is only mended by the promise of eternal life in heaven. And perhaps Tennyson's final acceptance of Hallam's death can be summed up in the famous lines, “'Tis better to have loved and lost,/ Than never to have loved at all” (XXVII.15-16). 


\section{BIBLIOGRAPHICAL INFORMATION}

Armstrong, Richard A. Faith and Doubt in the Century's Poets. New York: 1898.

Auden, W.H. A Selection From the Poems of Alfred, Lord Tennyson.Garden City,

New York: Doubleday \& Company, Inc., 1947. Print.

Barton, Anna. Alfred Lord Tennyson's 'In Memoriam': A Reading Guide.

Edinburgh University Press, 2012.

Beach, Wooster. Beach's Family Physician and Home Guide for the Treatment of the Diseases of Men, Women and Children on Reform Principles. Cincinnati: Moore, Wilstach, Keys \& Co., 1861.

Batchelor, John. Tennyson: To Strive, to Seek, to Find. First Pegasus Books Cloth ed. New York: Pegasus, 2013. Print.

Baum, Paul F. Tennyson Sixty Years After. Chapel Hill: U of North Carolina, 1948. Print.

Bradley, A. C. A Commentary on Tennyson's In Memoriam. Macmillan, 1907.

Buckley, Jerome Hamilton. "The Victorian Temper: A Study in Literary Culture." New York: Random House, Inc. 1964.

Chambers, Robert. Vestiges of the Natural History of Creation. United Kingdom, W. \& R. Chambers, 1884. 
Colby, Vineta. "Browning's 'Saul': The Exorcism of Romantic Melancholy." Victorian Poetry, vol. 16, no. 1/2, (1978), 88-99.

Colley, Ann C. Tennyson \& Madness. Athens: University of Georgia Press, 1983.

De L. Ryals, Clyde. “The 'Fatal Woman' Symbol in Tennyson” Modern Language Association vol. 74 no. 4 (1959), pp. 438-443

Eliot, T. S., Essays Ancient and Modern. Harcourt Brace and Company, 1936. Print.

Hallam Tennyson, Tennyson: A Memoir (London, 1897).

Hass, Robert Bernard. "The Mutable Locus Amoenus and Consolation in Tennyson’s In Memoriam.” Studies in English Literature: 1500-1900. Vol. 38.4 (1998): 669-87.

Hsiao, Irene. "Calculating Loss in Tennyson's 'In Memoriam.'” Victorian Poetry. Vol. 47, no. 1 (2009), pp. 173-196.

Jump, John D. “Tennyson's Religious Faith and Doubt”. Writers and Their Background. Tennvson. Palmer, D.J. G. Bell \& Sons, LTD., 1973. 89-114. 
Knowles, James. 'Remarks of Tennyson' in 'A Personal Reminiscence', The Nineteenth Century, XXXIII (January, 1893).

Langbaum, Robert Woodrow. The Poetry of Experience: The Dramatic Monologue in Modern Literary Tradition. New York: Norton, 1963. Print.

Miller, James E. T.S. Eliot's Personal Waste Land: Exorcism of the Demons. University Park: Pennsylvania State UP, 1977. Print.

Nicolson, Harold. Tennyson; Aspects of His Life, Character and Poetry. Boston, New York: Houghton Mifflin, 1925. Print.

Nunokawa, Jeff. "In Memoriam and the Extinction of the Homosexual." ELH, vol. 58 , no. 2 , 1991, pp. 427-438.

Ricks, Christopher. Tennyson: A Selected Edition. New York: Routledge Taylor \& Francis, 2014.

Riede, David G. “Allegories of One's Own Mind: Melancholy in Victorian Poetry." Columbus, Ohio State University Press, 2005. Print.

Riede, David G. “Tennyson's Poetics of Melancholy and the Imperial Imagination." SEL Studies in English Literature 1500-1900, vol. 40, no. 4 (2000), pp. 659-678.

Rosenberg, John D. "Stopping for Death: Tennyson's "In Memoriam"." Victorian Poetry 30.3/4 (1992): 291-330. Web. 
Rosenberg, John D. "Tennyson and the Landscape of Consciousness." Victorian Poetry 12.4 (1974): 303-10. Web.

Rosenberg, John D. "The Two Kingdoms of 'In Memoriam.”" The Journal of English and Germanic Philology, vol. 58, no. 2, (1959), pp. 228-240.

Sendry, Joseph. "“In Memoriam:" Twentieth-Century Criticism.” Victorian Poetry, vol. 18, no. 2, 1980, pp. 105-118.

Tennyson, Alfred. Tennyson's Poetry. Edited by Robert W. Hill Jr. $2^{\text {nd }}$ ed., New York: New York, W.W, Norton \& Company, Inc, 1999.

Tennyson, Alfred Tennyson, and Erik Irving Gray. In Memoriam: Authoritative Text : Criticism. Second ed. New York: W.W. Norton \&, 2004. Print. Norton Critical Edition.

Tennyson. Palmer, D.J. G. Bell \& Sons, LTD., 1973. 89-114.

Tichelaa, Tyler. “Christ, King Arthur, and Arthur Henry Hallam in Tennyson's Idylls of the King." Children of Arthur, 25 Nov. 2013.

Tucker, Herbert F. "Tennyson and the Measure of Doom.” Modern Language Association, vol 98, no. 1 (1983), pp. 8-20.

Van Dyke, Henry. Studies in Tennyson. New York: Kennikat, 1966. Print. 